\title{
Progrès réalisés par les turbines hydrauliques au cours des dernières années"
}

\author{
Hydraulic turbine development \\ during the last few years ${ }^{(\cdot)}$
}

\author{
par A. PUYO
}

DIRECTEUR DE LA DIVISION GROS MATÉRIEL NEYRPIC

\begin{abstract}
La technique des turbines hydrauliques, bien que d'origine ancienne, vient d'accomplir des progrès encore étonnants au cours de ces quinze dernières années.

Avec les progrès accomplis par les constructeurs électriciens et par les moyens de génie civil, il doit en résulter des perspectives prometteuses pour l'hydraulique, malgré la concurrence des autres sources d'énergie.

Ces progrès ont été dirigés principalement dans le sens de l'économie, dans le sens d'une plus grande facilité d'exploitation et dans le sens de la prolongation de la vie des machines. Ceci s'est traduit, d'une part, par des résultats spectaculaires tels que l'augmentation des puissances unitaires, l'augmentation des vitesses de rotation et la réduction des poids des machines, d'autre part par d'autres améliorations moins apparentes portant principalement sur la technologie mais dont l'incidence est également notable quant à la qualité des services rendus par ces machines.

Enfin, nous avons assisté également à la création et au développement de nouveaux types de machines tels que les Pelton verticales, les bulbes et les turbines-pompes. Ces nouvelles solutions, sans nul doute, contribueront $\dot{a}$ rendre plus compétitive l'énergie hydraulique au cours des prochaines années.
\end{abstract}

La concurrence des nouvelles sources d'énergie, tout spécialement de l'énergie nucléaire, a suscité certaines craintes sur l'avenir des équipements hydroélectriques. On pourrait donc se demander s'il est bien d'actualité de disserter sur les progrès des turbines hydrauliques. J'affirmerai, pour commencer, ma foi dans son avenir.

(*) Conférence prononcée à Mexico, lors des Journées techniques de l'exposition française, le 23 octobre 1962.

\begin{abstract}
The technique of hydraulic turbines originated many years ago, but it has nevertheless been possible to make amazing progress in the course of the last fifteen years.

In conjunction with the progress made by generator manufacturet's as well as on the civil engineering side, the futnre prospects for $h y-$ draulic power are extremely promising despite the competition from other sources of energy. Progress has been made principally with regard to improved economy, greater case of operation and longer equipment life. This has led, on the one hand, to spectacular results such as increased unit outputs and rotational speeds and a reduction in the weight of the equipment; and, on the other hand, to less obvious improvements, mainly in the technological field, the incidence of which is none the less remarkable with regard to machine performances.

Furthermore we have seen the creation and the development of new types of machines, such as vertical-shaft impnlse turbines, bulb anits and pump-turbines. These new solutions will without doubt contribute towards making hydraulic power more competitive in the course of the coming years.
\end{abstract}

One may well ask oneself whether this subject is still topical, especially as the future of hydraulic power may appear to be in the balance now that alternative sources of energy have become available, among which atomic power in particular. I shall begin review, therefore, by affirming my faith in the future of hydro-electricity.

(*) Paper read in Mexico, on occasion of the Technical Mectings at the French Exhibition (23rd Oct. 1962). 
Le développement de la production mondiale de charbon et de pétrole n'a pas affecté jusqu'à présent le rythme des aménagements hydroélectriques; la concurrence de l'énergie nucléaire n'est pas encore en vue avant quelques années; enfin il existe d'énormes possibilités d'aménagements de chutes d'eau, tout spécialement dans les pays neufs, et en particulier dans le domaine des basses chutes. Les centrales hydrauliques continueront donc, comme par le passé, à participer au diagramme de base de la consommation d'énergie électrique. Par ailleurs, les difficultés de réglage des centrales non hydrauliques conduiront à renforcer des installations hydroélectriques en vue d'assurer les pointes de consommation, en faisant souvent appel au pompage.

L'hydraulique a donc encore devant elle des perspectives prometteuses. Si elle a connu quelques menaces, elle a trouvé dans les ressources de sa propre technique des arguments pour faire face à ces menaces. Cast du reste la règle chaque fois qu'un être vivant, une collectivité, une conception, un procédé sont menacés; or, la technique hydroélectrique a connu des progrès évidents sous l'empire de la concurrence opposée par les autres modes de production d'énergie électrique. Ces progrès ont été marqués, pour le génie civil, par la puissance considérablement augmentée et l'extrême diversité des outillages de chantier. Ce sont eux, qui ont permis d'entreprendre des travaux d'une ampleur telle qu'il eut été folie, voici seulement quinze ans, de vouJoir les envisager; Infiernillo (1) en est une preuve éclatante. Ces progrès du matériel de génie civil ont aussi permis d'augmenter la rapidité des travaur; an cours des deux dernières décennies, le délai d'équipement d'une chute a été réduit de moitié.

Or, le poids très lourd des intérêts intercalaires pendant la construction constituait un désavantage marqué pour l'hydroélectricité; le raccourcissement des délais a donc bien constitué un facteur d'amélioration considérable en faveur de l'hydraulique.

De leur côté, les électriciens et les mécaniciens ne sont pas restés inactifs. En ce qui concerne les turbines hydrauliques, les recherches, tant du côté hydraulique que du côté mécanique, ont abouti à des résultats vraiment remarquables orientés principalement vers la réduction. des dimensions, des poids, donc finalement des prix, du matériel. Il en est résulté une augmentation très nette de la "puissance massique» des machines. En quelque sorte, pour une installation donnée, on a augmenté notablement le nombre de $\mathrm{kW}$, fourni par la machine, pour un

(1) Centrale en cours d'installation au Mexique et comportant quatre groupes de puissance maximale
235200 ch sous $112 \mathrm{~m}$ de chute.
The rate of hydro-power development has so far remained unaffected by the growth of world coal and oil production, and it will be a few years yet before atomic power can be produced on a competitive scale. In addition, tremendous hydro-power resources are still untapped, especially in the "new" countries, and mostly within the low-head range. Hydraulic power stations may therefore be expected to continue to enter into the basic electric power consumption pattern in future years. Furthermore, in view of the governing difficulties associated with non-hydraulic power production plant, the tendency will be to reinforce hydroelectric facilities, often by resorting to pumped storage, in order to be able to cater for peak demand requirements.

The outlook for hydraulic power thus appears to be quite bright. In the past, it has always been able to rely on its technical resources to see it through occasional difficult periods, just as human beings or communities do when in danger, or ideas, processes or methods in the face of a challenge. Hydro-power has invariably marked a step forward when threatened by competition from other methods of producing electricity. From the civil engineering point of view, this progress has taken the form of the development and use of substantially more powerful and varied work site equipment, with which projects can now be undertaken that it would have been sheer folly to even contemplate only fifteen or so years ago. A striking example of this is provided by the Infiernillo power scheme (1). The development more efficient civil engineering equipment has also resulted in much faster working rates, so much so in fact that the time required to equip a hydro-power site has actually been halved during the last twenty years. This has been an extremely favourable factor for hydro-electric projects, which have always been burdened with very heavy interest charges during the construction stage.

Steady progress has also been made in the electrical and mechanical fields. Remarkable results have been achieved in mechanical and hydraulic turbine research, especially in the form of reductions in component weights and sizes, and therefore also in equipment cost, together with a very marked increase in the "ontput per unit mass" of individual machines. In other words, turbines have been made to supply more electricity than ever before in relation to the amount of material used in their construction. This has been achieved both by widespread detail improvements on existing

(1) Power station in the course of construction and comprising 4 units of $235,000 \mathrm{HP}$, maximum output, 
poids de matière donné entrant dans sa constitution. Ceci a été possible grâce à l'amélioration, dans tous leurs détails, des types de machines existants, et aussi grâce à l'apparition de nouveaux types de turbines hydrauliques.

Nous allons examiner les progrès réalisés pour chacun des types de machines. Nous le ferons sous l'aspect d'un survol général de la technique, sans nous attacher à l'optique propre d'un constructeur donné. Nous représentons évidemment un constructeur, les Etablissements Neyrpic, mais nous essaierons, dans toute la mesure du possible, de nous dégager des intérêts particuliers pour donner une idée des progrès réalisés par la technique des turbines au cours des quinze dernières années. machines and by the development of entirely new hydraulic turbine designs.

We shall now examine the progress achieved with each machine type in turn in the form of a general review of the techniques employed; in this, we shall try to present an unbiased picture, without being influenced by the point of view of any one particular turbine manufacturer. Though we do represent a specific turbine firm-namely Etablissements Neyrpicwe shall try to ignore any particular interests in our discussion, in order to provide what we hope to be a fair general review of the progress achieved in turbine design during the last fifteen years.

\section{I. - TURBINES PELTON \\ I. - PELTON TURBINES}

\section{Augmentation des puissances unitaires.}

L'évolution des turbines Pelton a d'abord été marquée par une augmentation sensible des puissances unitaires. En 1950, on ne dépassait guère $50000 \mathrm{ch}$ par roue; quand on atteignait $100000 \mathrm{ch}$, c'était avec deux roues sur le même axe. En 1957, nous réalisions $112000 \mathrm{ch}$ par roue à Roselend. En 1961, $150000 \mathrm{ch}$ (à Sharavathi aux Indes), et nous proposons aujourd'hui $250000 \mathrm{ch}$ sur la même roue pour la centrale du Mont-Cenis.

\section{Augmentation des vitesses de rotation.}

Les vitesses de rotation et les vitesses spécifiques sont en progression. L'installation autour d'une même roue, dans les turbines verticales, d'un nombre élevé de jets, permet, pour une puissance et une chute données, d'utiliser des jets d'un diamètre plus petit que dans les turbines horizontales limitées à deux jets par roue. Les augets, moins larges et moins lourds, peuvent être calés sur un diamètre moyen beaucoup plus réduit, ce qui permet l'adoption de vitesses de rotations plus élevées.

En même temps, l'amélioration des tracés hydrauliques a permis des vitesses spécifiques par jet plus élevées pour une même chute (fig. 1). Au cours des dernières années, les constructeurs ont amélioré les formes des pointes d'augets, des lèvres d'échancrure, des arêtes, si bien que la cavitation, qui se manifestait principalement dans ces régions délicates de l'auget, a été éliminée. Ces améliorations sont dues non seulement aux essais sur modèles réduits, mais aussi à des

\section{Increases in output.}

Substantial increases in the outputs obtainable from individual turbines have been the primary success achieved in Pelton turbine development. Whereas 50,000 metric HP was just about the limit of what could be obtained from a single runner in 1950 , or 100,000 metric HP from two, on a common shaft, individual runner outputs of 112,000 metric $H P$ were being provided for the Roselend scheme by 1957, and 150,000 metric HP for Sharavathi, India, by 1961. Today, a single-runner output of 250,000 metric HP is being proposed lor the Mont Cenis plant.

\section{Increases in runner speed.}

Rotational and specific speeds are both steadily on the increase. By providing a large number of nozzles around an individual vertical turbine runner, smaller-diameter nozzles can be used for a given output and head than in horizontal-shaft machines, which are restricted to two nozzles for each runner. As the buckets can be made smaller and lighter, they can also be set on a much smaller mean diameter, with the result that higher running speeds can now be achieved.

Thanks to improved hydraulic designs, higher specific speeds per nozzles are now obtainable for a given head than ever before (Fig. 1). With 


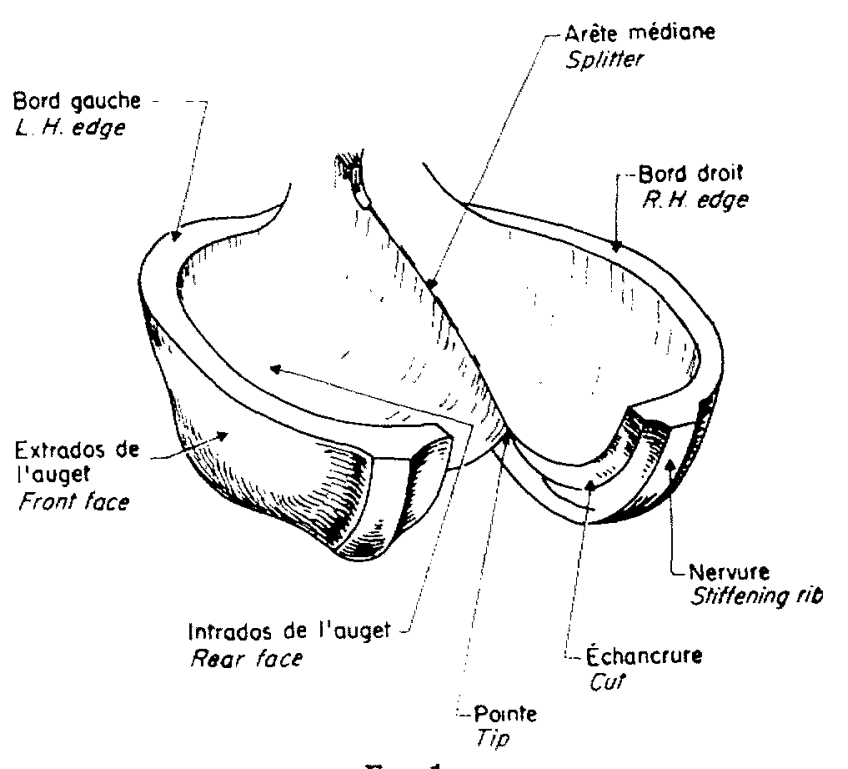

Frg. 1

Croquis d'un auget Pelton. Pelton bucket.

expériences pratiquées sur des turbines industrielles.

D'autre part, l'usage généralisé de l'acier inoxydable à haute résistance entrainait l'amélioration du tracé des attaches des augets sur leur couronne, des nervures de renforcement à l'arrière des augets, améliorant la tenue mécanique des roues. Ce sont tous ces facteurs qui ont conduit aux roues à trois, quatre, cinq et six jets.

Accroître la vitesse spécifique conduit à augmenter la vitesse de rotation soit, pour un nombre de jets déterminé, à augmenter le nombre d'impacts, c'est-à-dire le nombre de chocs supportés par la roue durant un temps donné; mais la fatigue du métal de la roue s'accroît avec le nombre d'impacts.

Le calcul de résistance d'une roue Pelton est très difficile et nous avons dû effectuer des essais d'extensométrie pour évaluer les fatigues réellement subies par les roues. Ces études ont conduit à des résultats intéressants. C'est ainsi qu'une roue, pourtant d'un tracé difficile, a fonctionné pendant $4 \times 10^{9}$ cycles sans apparition d'aucune fente de fatigue.

Par ailleurs, les contraintes propres des augets ont été considérablement réduites, comme conséquence indirecte des améliorations du tracé hydraulique. En effet, l'obtention de bons rendements à forte charge, généralement recherchée, s'obtient, pour un diamètre de jet donné, par l'élargissement des augets; comme la contrainte est inversement proportionnelle au carré de la largeur de l'auget, elle diminue rapidement quand cette largeur augmente. Or, le nombre d'impacts possible est, lui aussi, inversement proportionnel a la contrainte. C'est ce qui permet d'adopter une limite de nombre d'impacts the more efficient bucket tips and edges which have been developed during recent years, the cavitation which formerly mainly affected these delicate parts of the runner buckets has now been eliminated. This has been achieved both by model tests and by experiments carried out with turbines in industrial service.

Greater mechanical runner strength has been achieved by the more general use of high-tensile stainless steel, thanks to which improved designs have been developed both for bucket mountings and for the reinforcement ribs on the rear bucket faces. It is a combination of these various factors which has led to the development of three, four, five and six-nozzle runners.

The specific speed of a Pelton turbine is increased by running the machine faster, so that, for a given number of nozzles, the runner is subjected to a greater a number of impacts during a given time; the limiting factor in this case is metal fatigue, which increases with the number of impacts on the runner.

It is very difficult to calculate the strength of a Pelton wheel, and we have had to resort to strain gauge tests in order to assess the fatigue actually affecting our runners. These have yielded some very interesting results: for instance, one of the runners tested underwent $4 \times 10^{9}$ test cycles without showing any evidence of fatigue cracking.

Substantially lower bucket stresses have also been an indirect result of the improvements achieved in hydraulic design. It so happens that, for a given nozzle diameter, the high efficiencies which are usually required at high heads are achieved by increasing the bucket width, and, since the stress affecting a bucket is inversely proportional to the square of the bucket width, it decreases rapidly as the bucket width increases. Furthermore, as the possible number of impact affecting a bucket is also inversely proportional to the stress, it is possible to design to a fairly high limiting impact number. A current figure is 3,600 impacts per minute, for six nozzles and a speed of 600 r.p.m.

This possibility of increasing the number of impacts leads to higher runner speeds an a greater number of nozzles. Design and development involving both parameters has sometimes resulted in lower specific speeds per nozzle and a wider safety margin than on former machines, this even with an increased number of nozzles.

For example, whereas one would have met 
relativement importante : on atteint couramment 3600 impacts par minute, correspondant à six jets à $600 \mathrm{tr} / \mathrm{mnn}$.

La possibilité d'augmenter le nombre d’impacts se traduit par une augmentation à la fois de la vitesse de rotation et du nombre de jets.

L'évolution, englobant les deux paramètres, a été menée de telle façon que dans certains cas la vitesse spécifique par jet, même avec un nombre de jets plus élevé, se trouve être plus faible, donc comporte plus de sécurité, que par le passé. En voici un exemple : en 1950 , pour $62000 \mathrm{ch}$ sous $700 \mathrm{~m}$ on aurait choisi une roue et deux jets à $428 \mathrm{tr} / \mathrm{mn}$, soit une vitesse spécificue par jet de 21 et un nombre d'impacts de 856 ; en 1962, on prendrait une turbine verticale à six jets et $600 \mathrm{tr} / \mathrm{mn}$, soit 3600 impacts au lieu de 856, alors que la vitesse spécifique par jet ne dépasserait pas 17, au lieu de 21 .

L'augmentation de la vitesse spécifique-limite, pour une chute donnée, et l'augmentation du nombre d'impacts, se traduisent toujours par une augmentation de la vitesse de rotation, donc par une réduction des dimensions du groupe.

\section{Disparition des turbines horizontales.}

Tous ces facteurs ont entraîné, en pratique, la suprématie des machines à axe vertical sur celles d'axe horizontal.

Pour en donner une idée, sur 15 appels d'offres recus en dix-huit mois, il nous a été demandé 11 solutions en Pelton verticales contre 4 en horizontales. Sur les 11 solutions verticales, 5 intéressaient des machines dont la puissance unitaire variait entre 100000 et $250000 \mathrm{ch}, 3$ de 70000 à $90000 \mathrm{ch}$ et 3 de 18000 à $30000 \mathrm{ch}$.

Sur les 4 affaires de Pelton horizontales, l'une atteignait $70000 \mathrm{ch}$, les 3 autres se situaient entre 8000 et $28000 \mathrm{ch}$.

A l'heure actuelle, les moyennes et grandes puissances se traitent presque uniquement en unités verticales.

\section{Avantage des turbines verticales.}

Les avantages en sont nombreux. Avant lout, possibilité d'un grand nombre de jets, d'où vitesses de rotation plus élevées, donc alternateurs plus économiques. Ensuite, elles se prêtent mieux aux grandes puissances unitaires. De plus, elles entraînent un gain appréciable sur la chute nette, pour les chutes de 300 à $450 \mathrm{~m}$. Citons encore l'économie sur le génie civil, la section en plan de la salle des machines étant moindre que pour des turbines horizontales. Certains estiment que le démontage est plus facile que pour un groupe horizontal, mais c'est discutable. a 62,000 metric HP output and 700 metre head requirement with a twin-nozzle Pelton running at 428 r.p.m. in 1950 (i.e. a specific speed per jet of 21 and 856 impacts), the solution adopted in 1962 would be a vertical six-nozzle turbine running at 600 r.p.m. with 3,600 impacts instead of 856 , but with a maximum specific speed per jet of only 17 .

Both higher limiting specific speeds for a given head and increased impact numbers invariably also imply higher rotational speeds, that is to say smaller turbine dimensions.

\section{Obsolescence of horizontal Pelton tur- bines.}

As a result of these various factors, verticalshaft machines have gradually gained the ascendance over the horizontal-shaft design. An illustration of this tendency is provided by the fact that eleven out of fifteen tender specifications received during a period of 18 months called for vertical-shaft Pelton wheels, and only four for the horizontal design; five of the vertical machines were to be designed for individual outputs ranging between $100,000 \mathrm{HP}$ and $250,000 \mathrm{HP}$, three for $70,000 \mathrm{HP}-90,000 \mathrm{HP}$, and three for $18,000-30,000 \mathrm{HP}$.

One of the four horizontal machines was designed for a peak output of $70,000 \mathrm{HP}$, and the other three for outputs varying between $8,000 \mathrm{HP}$ and $28,000 \mathrm{HP}$.

Practically all the present medium and highoutput applications are now being catered for with vertical-shaft machines.

\section{Advantages of vertical-shaft Pelton tur- bines.}

Vertical Pelton units have many advantages to offer. First and foremost among them is the possibility of employing multiple nozzles resulting in higher turbine speeds and less expensive alternators, secondly, they are suitable where high individual outputs are required, thirdly, they result in a considerable gain in net head in the $300-450 \mathrm{~m}$ overall head range, and fourthly, by requiring less floor space in the power station, they enable a substantial saving in civil engineering costs to be achieved. Some people also maintain that they are easier to dismantle than horizontal machines, though this is rather a debatable point. 


\section{Evolution des Pelton verticales.}

\section{a) Groupes concenthés.}

Dans leur évolution, les Pelton verticales ont vu augmenter le nombre de jets; ensuite, s'est manifestée la tendance vers des groupes comprimés (fig. 3 et 4 ), deux paliers, le bâtí de la turbine supportant directement le stator de l'alternateur, et les vérins de freinage et de soulèvement du groupe.

La moitié des appels d'offres demandent des groupes tassés, même pour des puissances de $20000 \mathrm{ch}$, alors qu'autrefois cette solution était réservée aux groupes exceptionnels.

\section{b) BATIS.}

Il faut encore citer la simplification des bâtis. La fonte a été abandonnée au profit de la tôle. Des formes simples sont adoptées, polygonales jusqu'à 4 jets, cylindriques au-delà, et les bâtis sortent des ateliers sous forme de panneaux assemblés dans la centrale.

\section{Development of vertical-shaft Pelton tur- bines.}

\section{a) Compact POWER UNITS.}

The first stage in the development of verticalshaft Pelton turbines was an increase in their number of nozzles; this was followed by a trend towards more compact (Fig. 3 and 4) two-bearing units with the turbine casing directly carrying the alternator stator assembly and the bracking and turbine raising jacks.

Half the tender calls received specify compact units for outputs ranging up to $20,000 \mathrm{HP}$, whereas this type of layout was formerly restricted to exceptional cases.

\section{b) TURBINe CASINGS.}

Much simpler casing designs have been developed, with cast-iron giving way to steel plate as the construction material. Simple forms are used, which are generally polygonal up to four nozzles and circular beyond. The casings leave the factory as panels for assembly at the power house.

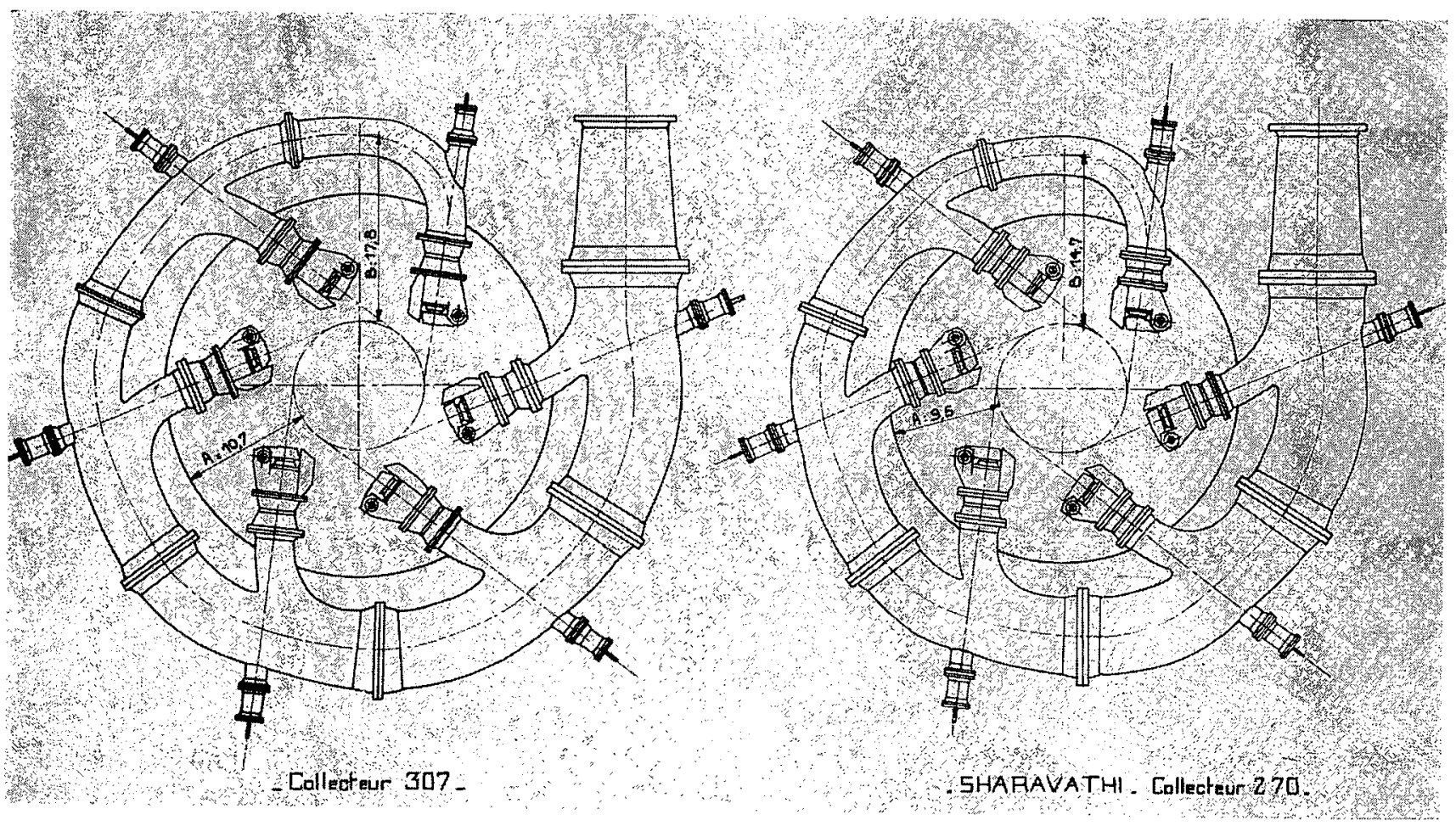

FIG. 2

Croquis des collecteurs $n^{\circ} 270$ (Sharavati) et $n^{\circ} 307$ à 6 injecteurs.

Nota : Les cotes $A$ et $B$ sont évaluées en fonction du diamètre du jet. Six-nozzle distribution manifolds 270 (Sharavati) and 307 Note: Dimension $A$ and $B$ depending on nozzle diameter. 
Fig. 3

Rioumajou (France). 1 turbine Pelton à axe vertical, 1 roue, 4 jets. Puissance : $7720 \mathrm{~kW}$. Chute : $280 \mathrm{~m}$ Vitesse : $600 \mathrm{tr} / \mathrm{mn}$ Coupe verticale de la centrale.

Rioumajou, France. One single-runner four-nozzle vertical-shaft Pelton turbine. Output: $7,720 \mathrm{~kW}$. Head: $280 \mathrm{~m}$. Speed: 600 r.p.m.

Vertical power house cross-section.
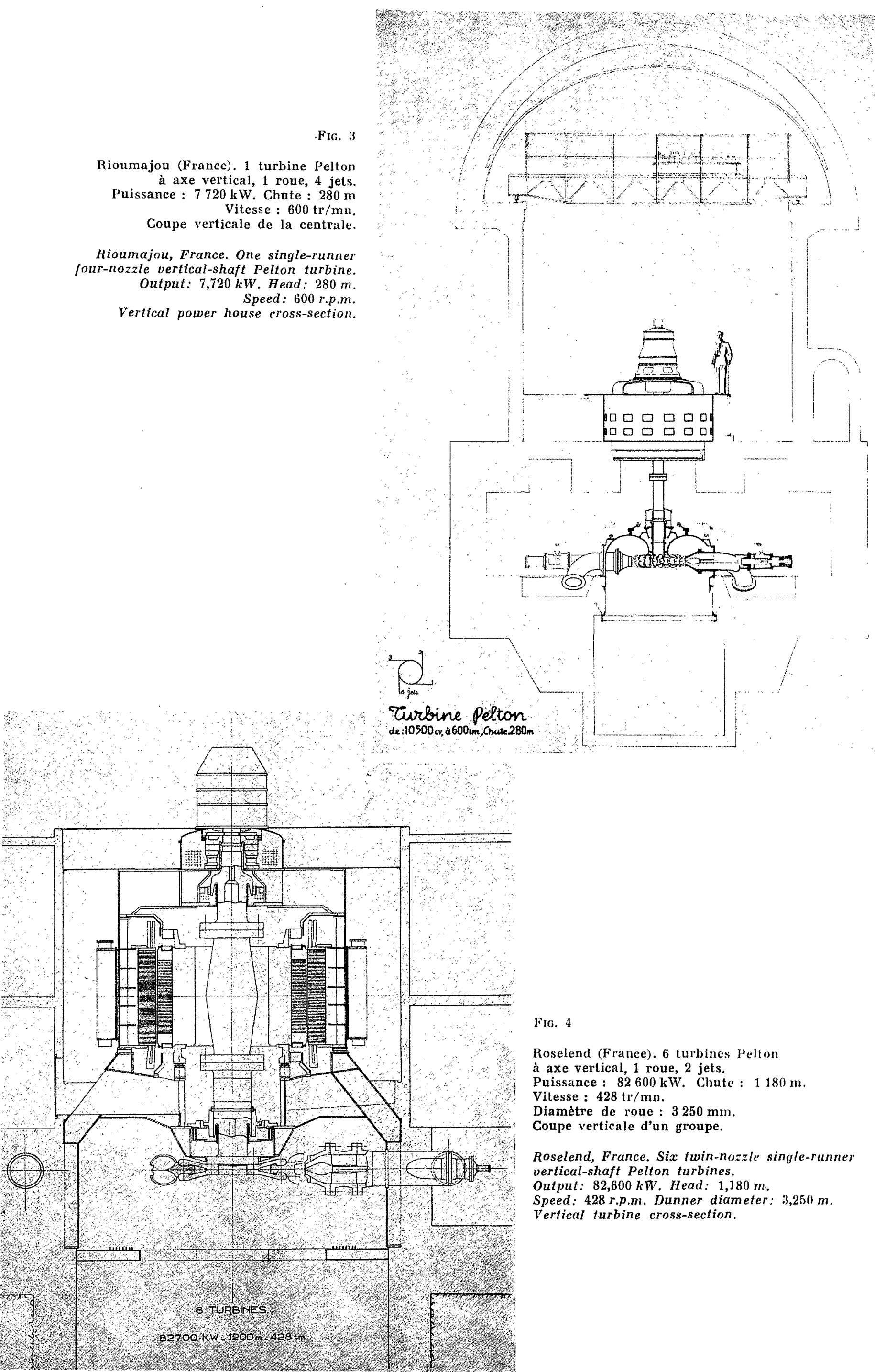

Fig. 4

Roselend (France). 6 turbines Pelton

$\dot{a}$ axe vertical, 1 roue, 2 jets.

Puissance : $82600 \mathrm{~kW}$. Chute : $1180 \mathrm{~m}$.

Vitesse : $428 \mathrm{tr} / \mathrm{mn}$

Diamètre de roue : $3250 \mathrm{~mm}$.

Coupe verticale d'un groupe.

Roselend, France. Six twin-nozzle single-runner vertical-shaft Pelton turbines.

Output: 82,600 kW. Head: $1,180 \mathrm{~m}$.

Speed: 428 r.p.m. Dunner diameter: $3,250 \mathrm{~m}$.

Vertical lurbine cross-section. 


\section{c) Roues.}

La tendance, pour les roues, va vers la réduction du nombre d'augets pour diminuer le poids. Des roues de même vitesse spécifique, qui comportaient 24 augets en 1947, n'en avaient plus que 18 en 1962.

La métallurgie des roues a progressé par l'élimination de l'acier ordinaire au profit de l'acier inoxydable, de meilleures caractéristiques mécaniques. Il permet, surtout pour les chutes élevées, l'amincissement des profils d'augets les rendant moins sensibles à la cavitation. Sa dureté plus élevée facilite la résistance à l'érosion. Pratiquement, l'acier ordinaire a disparu pour les chutes supérieures à $400 \mathrm{~m}$.

L'acier inoxydable utilisé comporte $13 \%$ de

\section{c) Runners.}

Modern runner design is tending towards a reduction of the number of buckets in order to save weight. For example, a 24-bucket runner designed for a given specific speed in 1947 would only have 18 buckets today.

Metallurgical progress achieved in runner design has consisted of replacing ordinary mild steel by stainless steel, which has better mechanical properties. Especially in the case of highhead applications, thinner bucket profiles less easily affected by cavitation can be adopted with the latter material, which, being harder, is also less readily affected by erosion. Ordinary steel is practically never used nowadays for heads of over $400 \mathrm{~m}$.

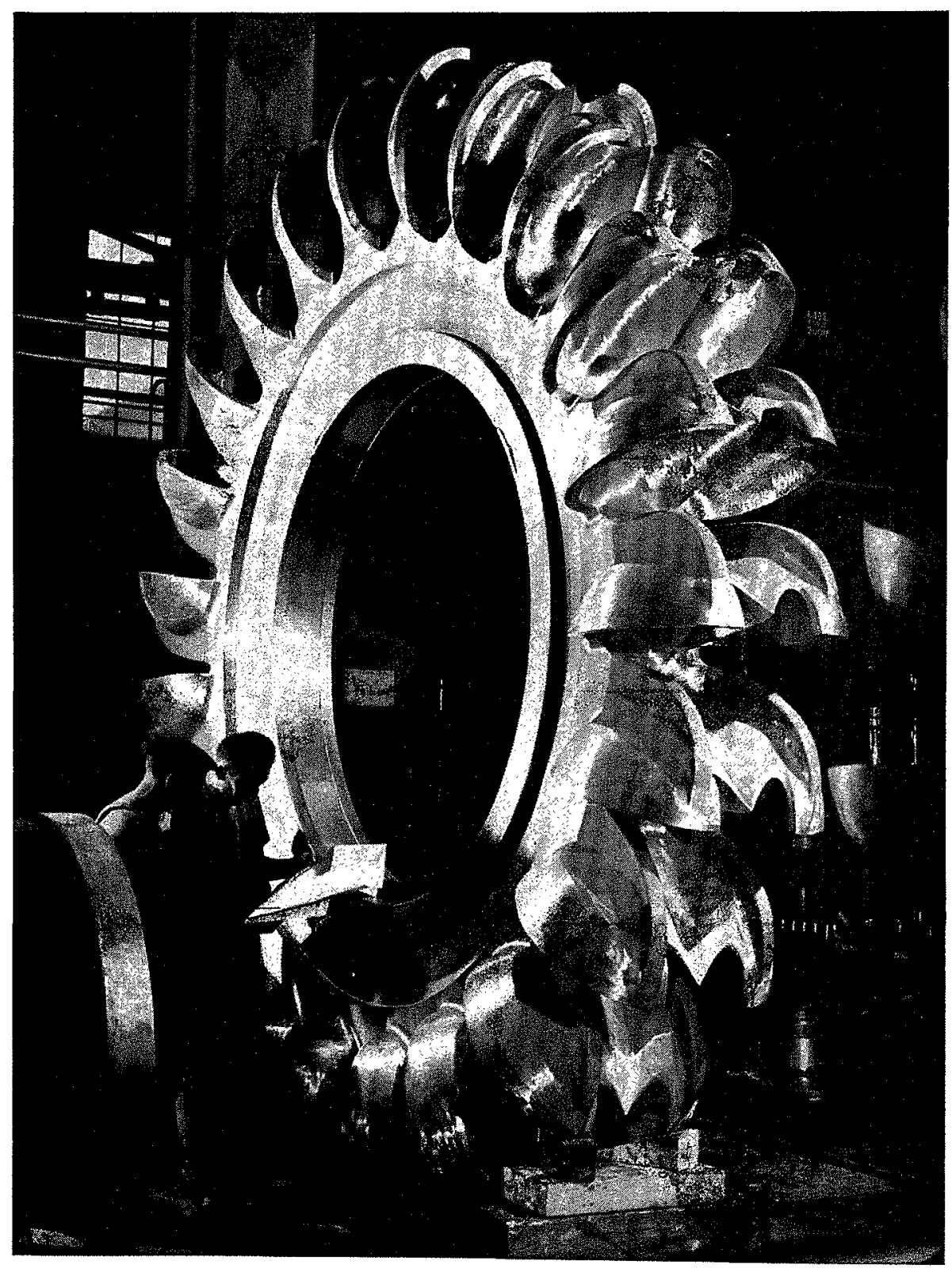

(Cliché Neyrpic.)
Fili. 5

Roselend

(caractéristiques : voir fig. 4)

Vérification en atelier d'une roue Pelton terminée.

Roselend

(characteristics: see Fig. 4). Inspection of a runner at the factory. 
chrome. Depuis quelques années l'acier à $17 \%$ de chrome et $4 \%$ de nickel est apparu. Il résiste encore mieux à la cavitation; ses caractéristiques mécaniques sont encore supérieures; surtout, sa soudabilité est bien meilleure, ce qui facilite la réparation des petits défauts de fonderie, difficile avec l'acier à $13 \%$ de chrome. Malheureusement, il est assez cher.

Dans la recherche d'une meilleure résistance à l'érosion, on a aussi essayé le chromage dur électrolytique de l'intérieur des augets et leur métallisation au pistolet avec de l'acier dur au carbone.

On a même exécuté des roues en bronze d'aluminium. Ce bronze, facile à couler, résiste très bien à la cavitation et se soude très facilement. Malheureusement, ses caractéristiques mécaniques assez faibles interdisent son emploi pour des chutes élevées, et sa résistance à l'usure par le sable est très mauvaise. Il convient donc de le réserver aux chutes de 300 à $400 \mathrm{~m}$, avec des eaux sans sable.

Comme perspective d'avenir il faut signaler la possibilité d'un retour à des roues à augets séparés.

Cette technique avait été abandonnée au profit des roues monobloc en raison des difficultés de fixation des augets. Mais les problèmes de fonderie augmentant avec l'accroissement du poids moyen des roues, la technique en est ensuite venue aux couronnes d'augets tenues par deux jantes, ce qui a permis la réalisation des roues récentes de 50000 à $100000 \mathrm{ch}$ (fig. 5 et 6 ).

Pour aller plus loin, vers des roues d'un poids dépassant $15 \mathrm{t}$, les problèmes de coulée des roues Pelton en acier à $13 \%$ de chrome deviennent très préoccupants; les difficultés de soudage de ces aciers, quand il y a des défauts - et il est fatal qu'il y en ait - sont toujours grandes. Mais surtout les moyens de contrôle : radiographie, ultra-sons, magnétoscopie, ont fait de tels progrès qu'ils ne pardonnent aucun défaut. C'est ce qui devrait amener dans un proche avenir à penser de nouveau aux roues à augets séparés, le mode de fixation restant à définir.

\section{Buses et pointes d'aiguilles :}

Les mêmes recherches de matériaux nouveaux ont été faites pour les buses et les pointes d'aiguilles, constituées en acier inoxydable à $13 \%$ de chrome, traité thermiquement pour lui donner une résistance de $150 \mathrm{~kg} / \mathrm{mm}^{2}$. De nouvelles solutions sont à l'étude et même ont été réalisées par l'Electricité de France : l'acier à outils extrêmement dur; les aciers « rapides», aciers au tungstène-molybdène-vanadium, et même les stellites coulées. Ce sont les matériaux utilisés pour les outillages de coupe des machines-outils.
The stainless steel used has a $13 \%$ chrome content; there has also been a tendency to use steel containing $17 \%$ chrome and $4 \%$ nickel during the last few years. This has an even better resistance to cavitation, better mechanical properties and, above all, it welds more readily, so that it is easier to repair minor casting flaws with this material than with $13 \%$ chrome steel, where it was always a difficult operation. This new steel is unfortunately rather expensive.

Attempts have been made to increase erosion resistance by electrolytically-applied hard chromium plating on the inside bucket faces, followed by a spray gun-applied hard carbon steel metallisation coating.

Some aluminium-bronze runners have also been produced. This is a good casting alloy which welds readily. As it unfortunately lacks the necessary strength for high-head applications, however, and only has very poor resistance to abrasive wear by sand, its use is restricted to the 300 to $400 \mathrm{~m}$ head range, and then only for water not containing any sand.

The possibility of a reversion to the practice of making Pelton wheels with separate buckets is worth noting. This practice had originally been abandoned in favour of integral castings because of the difficulties experienced in devising a satisfactory method of bucket attachment, but in view of the more difficult foundry problems associated with the heavier runners, a design has been developed featuring a buckel ring held to the wheel by two rims, which has been used in recent 50,000 HP to $100,000 \mathrm{HP}$ units (Fig. 5 and 6).

Beyond a weight of 15 tons, major problems arise in the casting of $13 \%$ chrome steel runners. The inevitable casting flaws are very difficult to make good by welding, added to which modern X-ray, ultrasonic and magnetic inspection methods have now reached such an advanced stage of development that they are able to detect even the slightest flaws in a casting. Designers may well be thinking in terms of wheels with separate buckets again before very long; a suitable form of bucket attachment would of course also have to be devised.

Nozzle and needle tips.

Similar reasearch has been going on with the object of finding new materials for nozzle and needle tips, which are made of $13 \%$ chrome stainless steel heat-treated to a strength of $150 \mathrm{~kg} / \mathrm{sq} . \mathrm{mm}$. New materials under investigation include the materials normally used for machine tools, i. e. very hard tool steel, highspeed steels, tungsten, molybdenum and vanadium steels and even cast stellite. Electricité de France has already tried some experimental components with these materials. 


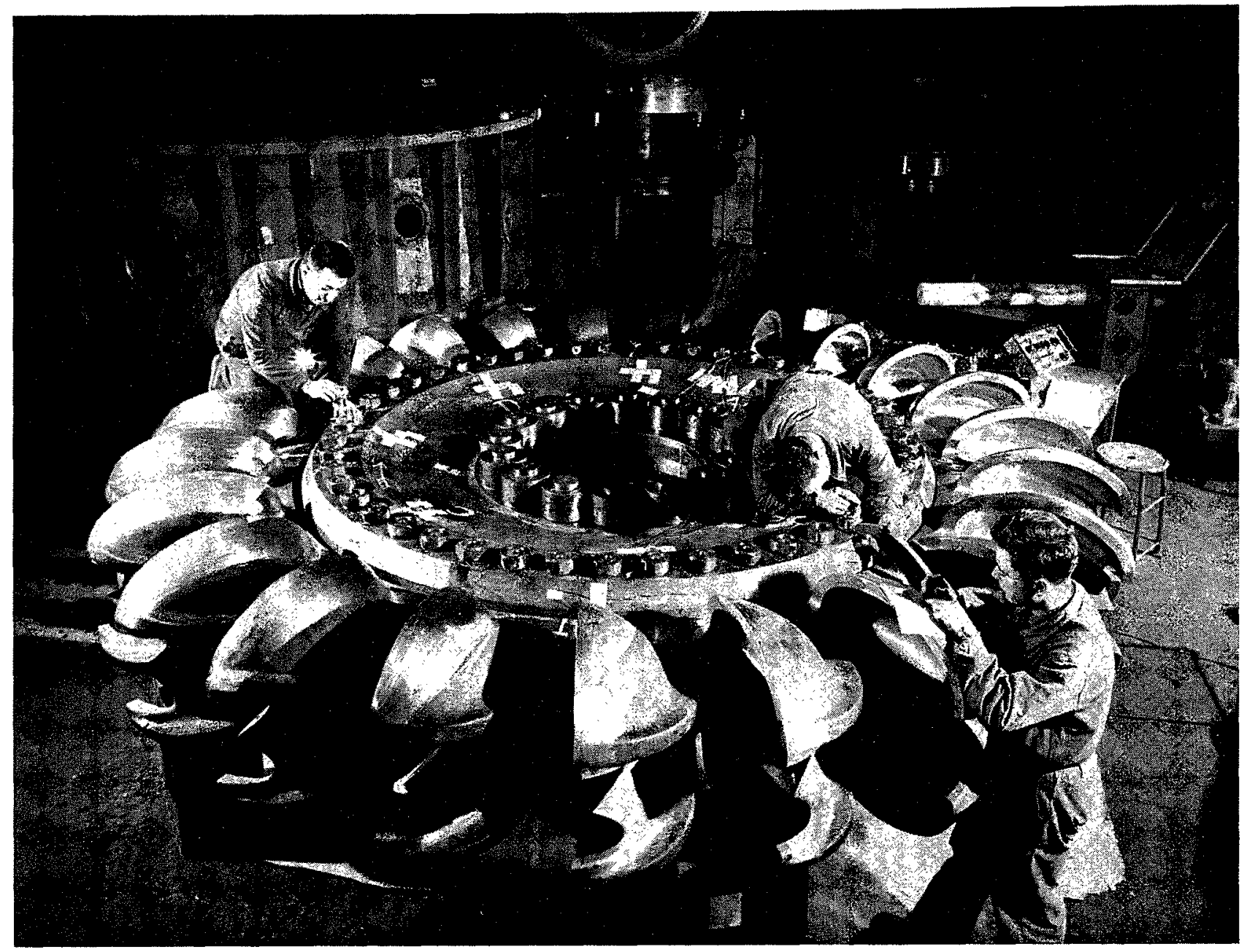

Fig. 6

(Cliché Neyrpic.)

Roselend (caractéristiques : voir fig. 4).

Mésures d'extensiométrie sur le disque et les boulons de fixation.

Roselend (characteristics: see Fig. 4).

Strain gauge measurements on the bucket ring and mounting bolts.

L'aiguille et le bec de buse sont souvent en deux pièces, dans un but d'économie et pour faciliter les rechanges. Ils sont démontables de l'extérieur, sans avoir à toucher à l'injecteur.

\section{Injecteurs :}

Pour les injecteurs, l'évolution conduit à retenir une tendance à fermer, pour les aiguilles.

Autrefois, certains constructeurs donnaient une tendance hydraulique à ouvrir, ce qui allait dans le sens de la sécurité en limitant les coups de bélier dans les fonctionnements troublés; d'autres donnaient une tendance à la fermeture. Actuellement presque tous s'orientent vers la tendance à fermer ou bien vers une tendance à fermer pour les faibles ouvertures, une tendance nulle à peu près au milieu de la course de l'aiguille d'injecteur et une tendance à ouvrir sur la fin de cette course. Ceci permet de sup-
The needle and nozzle tip liner are frequently made in two parts, both in order to save costs and to facilitate replacements. They can be dismantled from the outside without interfering with the nozzle.

\section{Nozzles.}

Present designs favour an inherent closing tendency for the needle. Certain manufacturers used to design their needles with an inherent opening tendency as a safety precaution against pressure surge under unsteady operating conditions, but nearly all now either favour a natural closing tendency throughout, or a tendency to close at small openings with a neutral tendency when the needle is roughly at its half-way position and an opening tendency over the final part of its travel. This has the advantage of doing away with balancing springs 
primer les ressorts d'équilibrage et de diminuer les dimensions du servo-moteur de commande de l'aiguille.

Enfin, les collecteurs des Pelton verticales ont été resserrés autour des bâtis. En cinq ans, pour des machines comparables, on a gagné de 13 à $28 \%$ sur l'implantation des collecteurs (fig. 2).

Je dirai encore un mot des injecteurs droits, préconisés par certains constructeurs. S'ils présentaient un intérêt pour les turbines horizontales à un jet par roue, ils en ont beaucoup moins pour deux jets, et ils n'en ont guère dans les turbines verticales. La complication des mécanismes de manœuvre ne justifie pas, à notre avis personnel, le maintien de cette technique. whilst enabling the dimensions of the needle servo motor to be reduced.

The intake manifolds of Pelton turbines have become more compact, and the manifold sizes of comparable machines have been reduced by about $13 \%$ to $20 \%$ in five years.

And now for a word or two about the straightthrough type of nozzle advocated by certain manufacturers. Though this was an attractive proposition for horizontal-shaft turbines with single runners its advantages are far fewer on twin-nozzle machines, and it has none at all to offer in the case of vertical-shaft turbines. Our own opinion is that the control mechanisms this type of nozzle requires are far too involved to warrant its use.

\section{II. - TURBINES FRANCIS \\ II. - FRANCIS TURBINES}

\section{Augmentation de la puissance unitaire.}

L'évolution s'est encore dirigée vers l'accroissement des puissances unitaires. Mais, pour les turbines Francis, cette tendance est déjà ancienne. Dès 1945, d'assez nombreuses turbines dépassaient la puissance unitaire de $100000 \mathrm{ch}$. En France, dès 1947: $135000 \mathrm{ch}$ à Chastang, $150000 \mathrm{ch}$ à Bort.

Puis, nous avons atteint $180000 \mathrm{ch}$ à Bersimis au Canada, $170000 \mathrm{ch}(2)$ à Aldeadavila en Espagne, pour aboutir aux machines de $235000 \mathrm{ch}$ d'Infiernillo, record actuel du Monde occidental. Les Russes ont dépassé ces puissances et atteint $350000 \mathrm{ch}$. On parle de projets, russes ou américains, de $400000,500000 \mathrm{ch}$ et même $500000 \mathrm{~kW}$.

La limite sera donnée par des questions de fonderie de roues, d'outillage et de capacité de transport.

\section{Augmentation des chutes.}

Dans ces dernières années, le domaine d'emploi des turbines Francis a continué de s'étendre vers les chutes élevées, en concurrence avec les Pelton. J'avais étudié cette question voici une douzaine d'années enviror dans la revue La Houille Blanche où mon rappor' avait entraîné d'intéressantes discussions. Quoi qu'on ait pu en penser à l'époque, je ne suis pas un partisan aveugle des Pelton. Il est certain que les Francis, permettant des vitesses plus élevées, sont beaucoup plus économiques. Ce que je prétendais démontrer, c'est qu'il ne

(2) $195000 \mathrm{ch}$ aux essais.

\section{Increases in output.}

One of the aims in the development of Francis turbines has been to increase individual outputs. This trend dates much farther back than in the case of the Pelton turbine, however, for a number of Francis units had already passed the 100,000 HP mark by 1945, and the year 1947 saw the commissioning of $135,000 \mathrm{HP}$ units at Chastang and $150,000 \mathrm{HP}$ units at Bort, both in France. These were followed by $180,000 \mathrm{HP}$ at Bersimis in Canada, $170,000 \mathrm{HP}(2)$ at Aldeadavila in Spain and, finally, the 235,000 HP turbines at Infiernillo, which are the most powerful in the western world today. Units producing $350,000 \mathrm{HP}$ have been built in Russia, and there is some talk of Russian and American projects for $400,000 \mathrm{HP}, 500,000 \mathrm{HP}$, and even $500,000 \mathrm{~kW}$. Just how much further this development can go will depend on runner casting, tooling, and transport capacity problems.

\section{Increases in head.}

The range of applications of the Francis turbine has been extending towards the higher head range during the last few years, which was formerly the sole preserve of the Pelton Lurbine. I had already studied this question about twelve year's ago, when I published an article in ' $L a$ Houille Blanche' on the subject, which led to a number of interesting discussions. Contrary to what some people seemed to think at the time, I am by no means a blind supporter of the Pelton turbine. For one thing, Francis

(2) $195,000 \mathrm{HP}$ on testing. 
faut pas limiter la comparaison des deux types de machines, lorsqu'elles sont en concurrence, à celle des frais d'investissement, mais tenir compte également des frais d'exploitation, qui dépendent, dans le cas des Francis, de la qualité des eaux turbinées. Si ces eaux sont pures, la Francis l'emporte; mais si les eaux sont très chargées, sans réservoir d'alimentation, l'exploitant doit se poser le problème d'optimum économique; car l'entretien est notablement moins coûteux avec des turbines Pelton. ILe bilan de premier établissement ne se suffit pas; c'est ce que je voulais prouver et mes conclusions subsistent.

Aujourd'hui presque tous les constructeurs sérieux ont réalisé des Francis pour des chutes de 300 à $400 \mathrm{~m}$; l'un a dépassé $500 \mathrm{~m}$, et on a même proposé $600 \mathrm{~m}$. La limite sera donnée par les difficultés de fonderie. Les chutes élevées conduisent à des tracés d'aubages extrêmement serrés. La progression vers les hautes chutes a été favorisée par les progrès de la métallurgie, capable de couler des roues aussi difficiles, par une meilleure connaissance de la cavitation, grâce aux progrès réalisés en laboratoire sur la visualisation de l'écoulement sous les roues d'essai. Elle a été favorisée également par les progrès de la résistance des matériaux, qui sait mieux calculer les bâches.

\section{Augmentation des vitesses de rotation.}

L'amélioration des tracés hydrauliques entraîne la réduction des vitesses d'emballement, ce qui, pour une même vitesse, permet des alternateurs plus économiques.

L'augmentation des vitesses de rotation oblige à enfoncer les groupes par rapport au niveau aval pour se mettre à l'abri de la cavitation. Grâce aux progrès du matériel de génie civil, creuser plus profondément n'est plus une entreprise aussi coûteuse qu'autrefois. La plupart des grandes centrales étant souterraines, c'est. encore un élément favorable.

\section{Amélioration des rendements.}

Par contre, et contrairement à ce qu'on pourrait penser, il n'y a pas eu progression sensationnelle des rendements. Ceux-ci plafonnent depuis quelques années, mais à des altitudes tellement élevées qu'il est difficile, et assez illusoire, d'aller plus loin. Quand on passe de 93,5 à $94 \%$ j'ai bien l'impression que le choix des moyens d'essai, le soin apporté à ces essais revêtent beaucoup d'importance et laissent planer une légère incertitude sur la vérité des comparaisons faites à quelques dixièmes de points près.

Ce que l'on a plutôt cherché à faire, c'est de réduire considérablement les dimensions pour rendre les machines plus économiques et là, turbines are much more economical because of the higher speeds at which they can be run. The point I was trying to make was that, instead of limiting a comparison between the two machines when in direct competition to a consideration of their respective first costs, one should also take their running costs into account; these, in the case of the Francis turbine, depend on the quality of the water passing through the machine. The Francis is the better machine in clean water, but where the water carries much sediment and there is no storage reservoir, the problem of optimum economy becomes the one to consider, for the maintenance costs for Pelton turbines are by far the lower of the two. What I wanted to show twelve years ago was that no definite decision can be based on initial costs alone. I still hold this view today.

Most leading turbine manufacturers have produced Francis machines for heads ranging between $400 \mathrm{~m}$ and $500 \mathrm{~m}$, and one has even gone farther. The ultimate limit will depend on casting problems, because of the very closely spaced blading designs required for high-head applications. Progress in the higher head range has been assisted by developments in metallurgy which have enabled such difficult castings as these big Francis runners to be produced, by progress in cavitation research, and by the development of new experimental methods enabling the flow underneath test rumners to be observed visually. The additional knowledge gained about the strength of materials has also been of invaluable assistance to turbine casing designers.

\section{Increases in running speeds.}

Improved hydraulic designs have resulted in lower runaway speeds and more economical alternators.

The increase in turbine speeds has made it necessary to set the machines lower down with respect to the downstream water level so as to prevent cavitation, which, thanks to developments in civil engineering techniques, is not nearly the expensive undertaking it used to be. As most of the bigger power stations are of the underground type, the lower turbine setting level is yet another favourable factor.

\section{Increases in turbine efficiency.}

Contrary to what one might have expected turbine efficiencies have remained pretty well stationary during the past few years, though at such high values that it would be both difficult and meaningless to push them up any further. 
vraiment, les progrès ont été considérables, Par exemple, en France, Génissiat a été longlemps considérée comme une centrale pilote; eh! bien, si nous devions refaire les mêmes turbines, leur poids serait aujourd'hui à peine plus de la moitié du poids des machines de 1945 .

Pour un même diamètre de roue, le diamètre de perçage du distributeur, diamètre de la circonférence le long de laquelle sont placées les aubes du distributeur, a été sensiblement réduit.

\section{Turbines horizontales.}

Comme pour les Pelton, les turbines Francis horizontales vont disparaissant, sauf pour les petites unités.

Seule exception : Ies turbines des stations de pompage car, à ce jour, il est considéré comme beaucoup plus facile d'installer un groupe turbine-alternateur-pompe en position horizontale qu'en position verticale. Ce ne sera peut-être pas la vérité demain. Nous venons de participer, avec d'autres constructeurs, à la fabrication de turbines horizontales d'une puissance unitaire de $145000 \mathrm{ch}$ pour une station de pompage au Luxembourg.

Je voudrais dire un mot des turbines d'axe horizontal à tuyau d'aspiration droit (fig. 7). Un certain nombre d'aménagements ont été ainsi réalisés, souvent sur les directives du grand ingénieur-conseil, M. Harza. Ces machines ont donné des rendements excellents (3). Toutefois, cette disposition paraît limitée aux machines de très grande puissance spécifique où l'aspi-

(3) En France, turbine de Soulom, pour la S.N.C.F. $16500 \mathrm{~kW}$ sous $118 \mathrm{~m}$. Rendement $94,3 \%$
I cannot help feeling that a claim to have increased a turbine efficiency from, say, $93.5 \%$ to $94 \%$ needs viewing with some reserve, for the experimental equipment used and the amount of care taken with the tests must obviously count for a great deal. The reliability of comparisons involving differences of only a few tenths of a per cent is rather doubtful to say the least.

Much attention has been given to the problem of substantially reducing machine dimensions with a view to producing more economical turbines, and considerable progress has in fact been made in this direction. In France, for instance, Génissiat was for a long time considered to be a kind of pilot station, but if the same turbines were to be redesigned today, they would only weigh just over half as much as the original machines built in 1945 .

The guide vane ring pitch diameter circles (i.e. the diameter of the circle along which the holes for the guide vane stems are drilled) for given runner diameters have also been substantially reduced.

\section{Horizontal-shaft Francis turbines}

Except for smaller-sized machines, horizontal-shaft Francis turbine are gradually on the way out. The only major exception occurs in the case of turbines in pumped storage schemes, as it is still considered much easier to install a turbine-alternator-pump unit in the horizontal position than upright, though it is

Fig. 7

Ambuklao (Philippines)

3 turbines Francis

à axe horizontal.

Puissance : $29474 \mathrm{~kW}$. Chute : $174 \mathrm{~m}$

Vitesse : $360 \mathrm{tr} / \mathrm{mn}$

Coupe longitudinale de la centrale.

Ambuklao, Philippines. Three horizontal-shaft Francis turbines.

Output: $29,474 \mathrm{~kW}$.

Head: 174 m. Speed: 360 r.p.m. Longitudinal section through the power house.

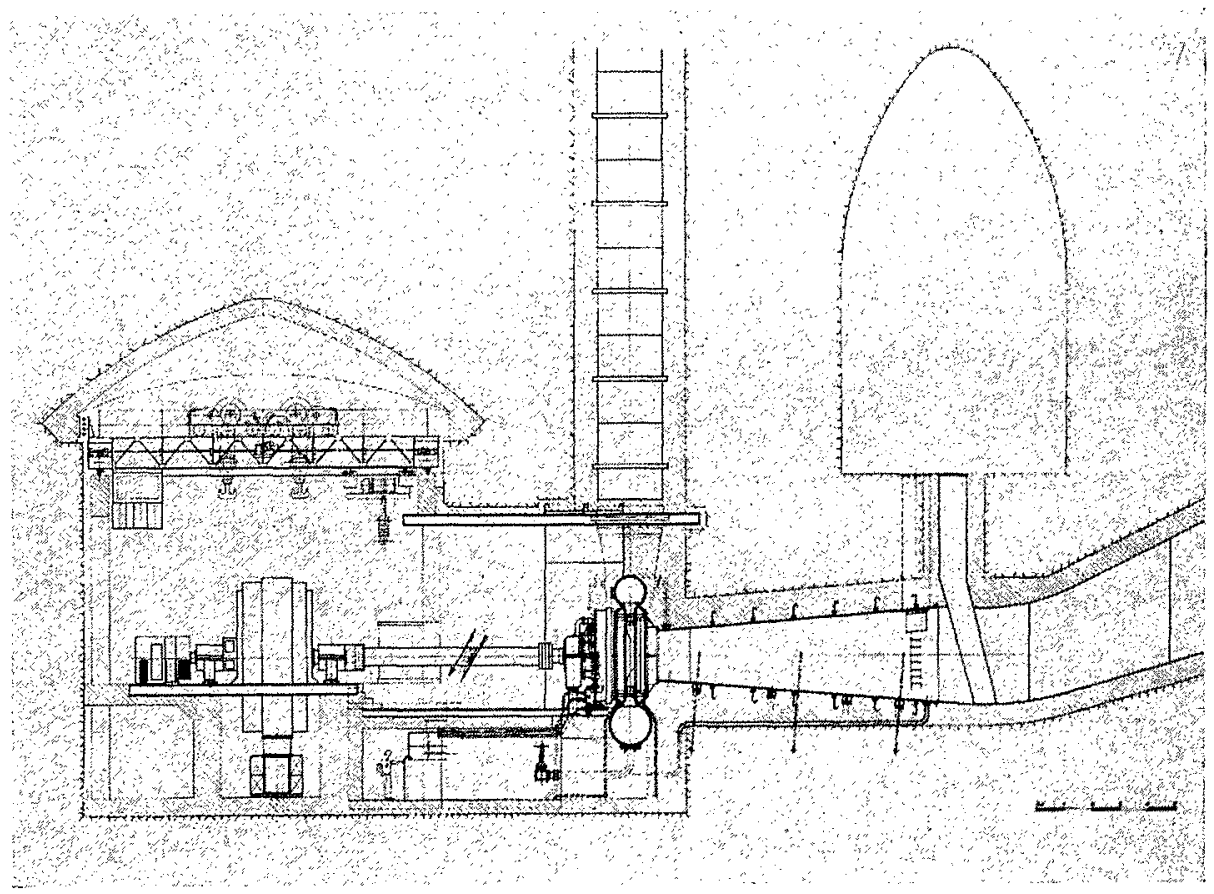


rateur récupère une part très importante de l'ćnergie. L'aspirateur droit, d'un bien meilleur rendement que l'aspirateur coude, prend alors tout son intérêt.

\section{Turbines Francis doubles.}

De même, les turbines Francis doubles disparaissent peu à peu; elles avaient pourtant l'avantage, à calage égal par rapport au niveau aval, de tourner plus vite et leur rendement était excellent.

Nous avons par exemple réussi des turbines doubles de $30000 \mathrm{ch}$ sous $250 \mathrm{~m}$, qui ont donné un rendement de $93,5 \%$. Mais, généralement, les turbines doubles, pour de grandes vitesses spécifiques et d'assez grandes puissances, présentent un arbre très gros au travers de l'aspi-

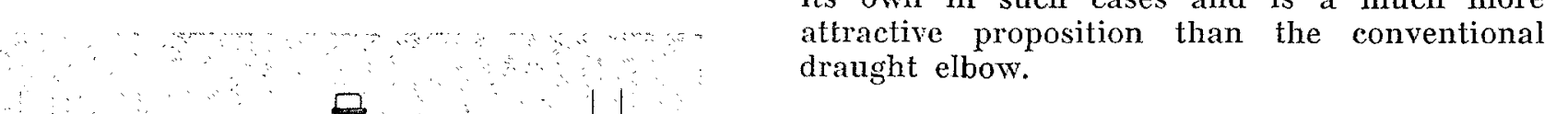

\section{Double Francis turbines.}

Double Francis turbines are also gradually becoming obsolescent, despite their advantage of running faster and producing excellent efficiencies for a given height setting above the downstream water level. We ourselves have successfully built $30,000 \mathrm{HP}$ double turbines with an efficiency of $93.5 \%$ for a head of $250 \mathrm{~m}$. Generally speaking, however, the trouble with this type of turbine is that if designed for a fairly high output and a high specific speed, it inevitably requires a very big shaft running through the draught tube, which reduces its efficiency and thereby limits its possible applications.

\section{Dismantling of turbines.}

Power unit dismantling provisions should reasonably be counted among the general arrangements provided for power unit management purposes, and a few words should be

(3) Soulom power station (French National Railways) : $16,500 \mathrm{~kW}$, under $118 \mathrm{~m}$, efficiency $94.3 \%$.

\section{Fig. 8}

Aldeadavila (Espagne). 6 turbines Francis à axe vertical. Puissance : $124950 \mathrm{~kW}$. Chute : $139 \mathrm{~m}$. Vitesse : $187,5 \mathrm{tr} / \mathrm{mn}$ Coupe transversale d'une turbine.

Aldeadavila, Spain, Six vertical-shaft Francis turbines. Output: $124,950 \mathrm{~kW}$. Head: $139 \mathrm{~m}$. Speed: $187.5 \mathrm{r} . \mathrm{p.m}$.

Vertical turbine cross-section. 


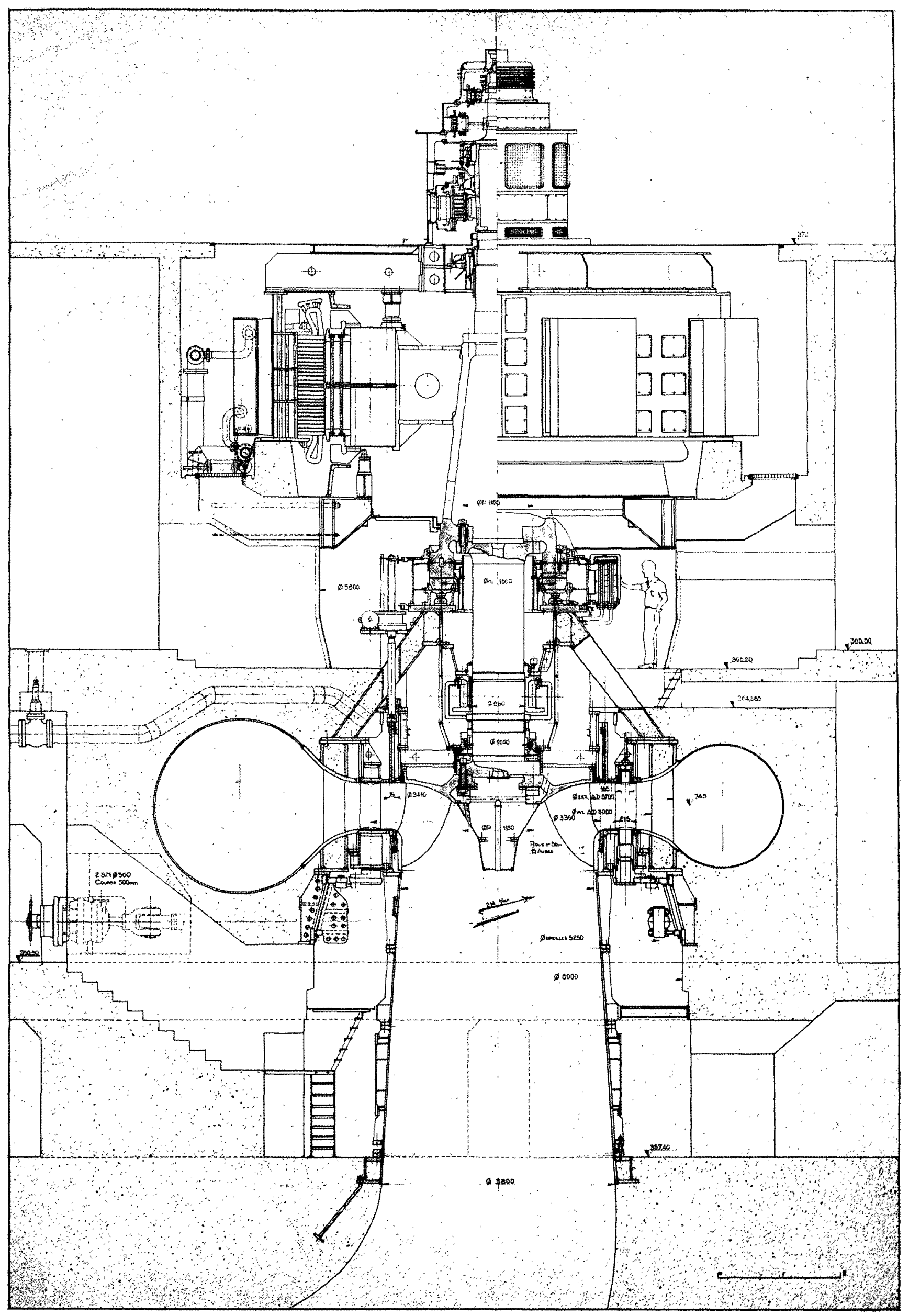

FIg. 9

Monteynard (France). 4 turbines Francis à axe vertical. Puissance : $82300 \mathrm{~kW}$. Chute : $125 \mathrm{~m}$. Vitesse : $214 \mathrm{tr} / \mathrm{mn}$. Monteynard, France. Four vertical-shaft Francis turbines. Output: $82,300 \mathrm{~kW}$. Head: $125 \mathrm{~m}$. Speed: $214 \mathrm{r.pm}$. 
rateur, ce qui entraine une baisse de rendement et limite leur emploi.

\section{Démontage des groupes.}

Dans l'optique des dispositions générales prévues pour les groupes, il convient d'envisager les modes de démontage adoptés, car ils réagissent sur toute la structure de la centrale.

A travers le temps et aussi en fonction des dimensions des groupes, on a d'abord effectué les démontages à l'étage intermédiaire, c'est-àdire entre turbine et alternateur, puis la mode est. venue au démontage par en dessous, puis, enfin, au démontage au travers de l'alternateur.

Le démontage d̀ l'étage intermédiaire (fig. 8) présente l'inconvénient d'une grande longueur d'arbre, ce qui entraîne des inconvénients au point de vue de la vitesse critique de la ligne d'arbre. Les démontages sont faciles mais la disposition n'est pas toujours économique.

Cependant Génissiat, Aldeadavila (six fois $170000 \mathrm{ch}$ ) sont réalisés sur ce modèle. Actuellement, cette conception est plutôt réservéc aux machines de haute chute; les vitesses de rotation élevées conduisent à des diamètres de rotor d'alternateur relativement faibles; les pièces de la turbine ne peuvent pas passer au travers de l'alésage du stator. Le démontage par en dessus est donc interdit et, par ailleurs, le démontage par en dessous n'est pas davantage possible puisque le diamètre de sortie de la roue est très inférieur au diamètre d'entrée.

Le démontage par en dessous (fig. 9), très utilisé vers 1945 , avait été quelque peu abandonné, mais actuellement il est redevenu classique en France. II faut renforcer fortement le cône à la sortie de la roue. II complique les fondations, mais on estime que le démontage pour changement de la roue est beaucoup plus rapide. Reste à savoir s'il faut souvent démonter une roue d'une très grosse unité.

Enfin, le démontage au travers de l'alternateur (fig. 10), dont la mode nous est venue d'Amérique vers 1950, a été très pratiqué en Europe, mais paraît moins en faveur actuellement. Il conduit à sortir le rotor de l'alternateur pour avoir accès aux pièces de la turbine. Operation relativement rapide, mais que certaines sociétés n'admettent plus.

\section{Les groupes concentrés (fig. 10).}

Dans le but de réduire le génie civil des centrales, aériennes ou souterraines, les groupes ont été de plus en plus concentrés en hauteur. Ces groupes sont à deux paliers, le palier supérieur pouvant être situé en dessus ou en dessous de l'alternateur, suivant la vitesse de rotation $\mathrm{du}$ groupe. Le pivot est très fréquemment disposé sur le plafond de la turbine, ce qui added about them, therefore, as they condition the structure of the power station as a whole.

Three dismantling methods have been adopted at various times, depending on the size of power unit concerned. In the early days, the dismantling operations used to be carried out from the intermediate floor (i.e. between the turbine and the alternator), but later on, preference was first given to dismantling from below, and then to dismantling through the alternator.

Dismantling from the intermediate floor (Fig. 8). The disadvantage of this arrangement is that it means having a very long turbine shaft dealing and with all the attendant critical speed problems. Though it makes for easier dismantling this type of layout is not always very economical.

Nevertheless, both Génissiat and Aldeadavila (six 170,000 HP units) are designed along these lines. Arrangements of this type are usually reserved for high-head machines nowadays, for as the high speeds at which they run require comparatively small alternator rotors, the alternator casings are too small to allow the turbine parts to be withdrawn through the stator assembly. Dismantling from underneath the unit would also be pointless in this case, as the runner exit diameter is much smaller than the inlet diameter.

Dismantling from underneath the unit (Fig. 9). Though very popular around 1945, this method gradually fell into disuse until recently, when it again became current practice in France. It is considered to enable the runner to be dismantled in much less time than by other methods, but requires a substantially reinforced runner exit cone and more complicated foundations. It now remains to be seen whether or not the runners of very big units will need dismantling at frequent intervals.

Dismantling through the alternator (Fig. 10). 'Imported' from America in 1950 or thereabouts, this method initially also found widespread use in Europe, but its popularity now seems to be declining. It involves removing the alternator rotor in order to gain access to the turbine components. The operation can be completed fairly quickly, but is not considered acceptable by certain firms.

\section{Compact Francis units (Fig. 10).}

Attempts have been made to cut down on the height of the unit in order to be able to also reduce the amount of construction work required in both surface and underground power stations. Compact units have two bearings, the upper one of which is either above or below the alternator, depending on the turbine speed. The thrust bearing is very frequent- 


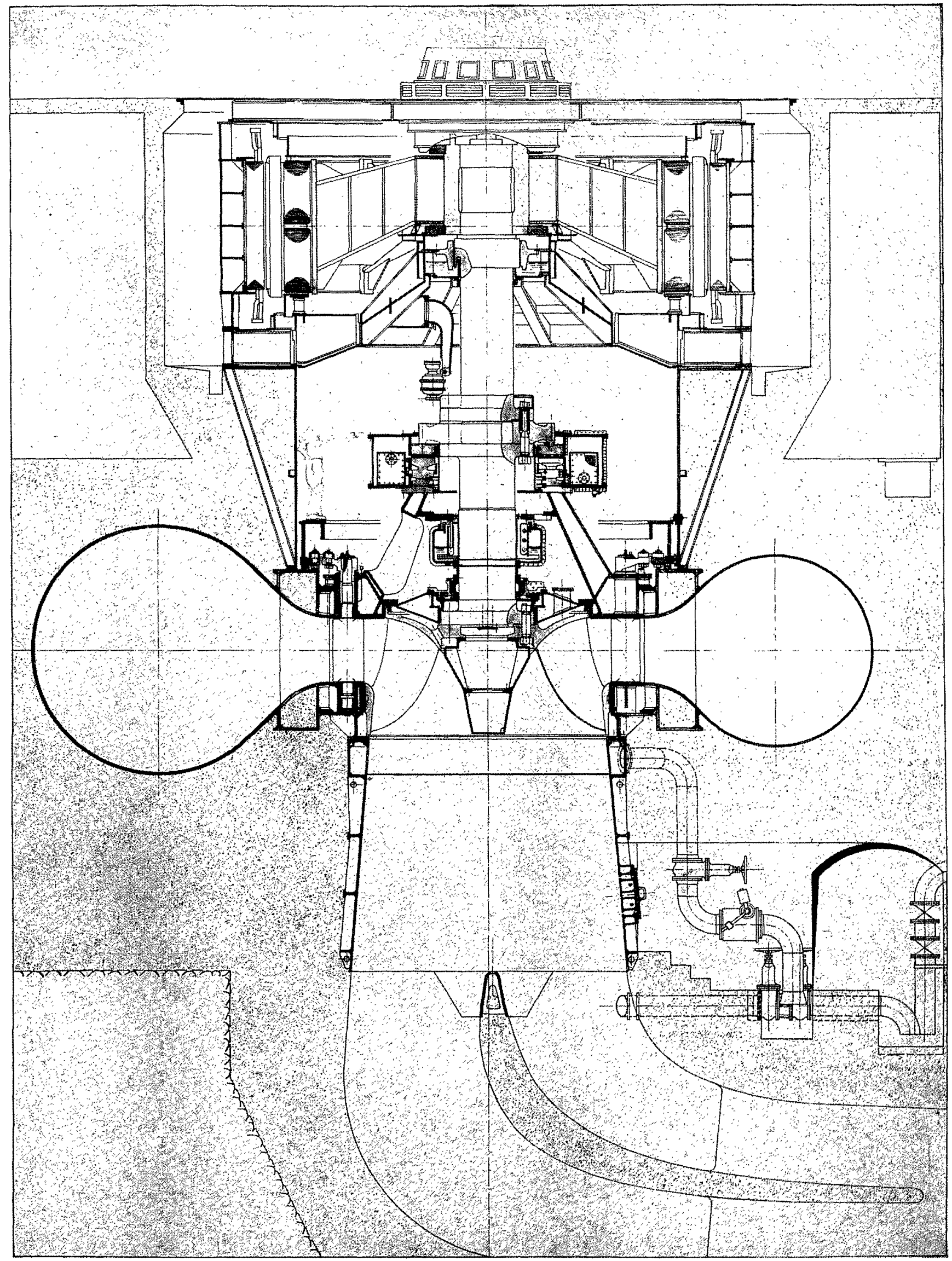

FIG. 10

Picote (Portugal) 3 turbines Francis à axe vertical

Puissance : $66600 \mathrm{~kW}$. Chute: $70 \mathrm{~m}$. Vitesse : $166 \mathrm{tr} / \mathrm{mn}$. Coupe verticale d'unc turbinc.

Picote, Portugal. Three vertical-shaft Francis turbines.

Output: $66,600 \mathrm{~kW}$. Head: $70 \mathrm{~m}$. Speed: $166 \mathrm{r.p.m}$. Vertical turbine cross-section. 
compense en partie la poussée hydraulique sur ce plafond. Le croisillon d'alternateur n'a plus qu'à supporter un palier-guide. La disposition du pivot sur le fond exige un diamètre de perçaģe du distributeur suffisamment grand pour permettre un montage et un accès faciles.

\section{Dispositions contructives.}

J'en arrive aux éléments constitutifs de la machine.

\section{LES BACHES :}

Leurs dimensions ont été sensiblement réduites dans toutes les directions.

Les études théoriques de grilles d'aubage fixes, la visualisation des écoulements en labo- ly fitted to the turbine head cover so as to partly compensate for the hydraulic thrust acting on this particular component, and the alternator spider merely carries a guide bearing. With this thrust bearing arrangement, the distributor ring pitch circle diameter. has to be made big enough to allow for convenient assembly and accessibility.

\section{Component design trends.}

We shall now briefly review the various components of a Francis turbine.

\section{Spiral CaSings.}

All the spiral casing dimensions have been substantially reduced. Much smaller spiral diameters are now possible thanks to comprehensive theoretical research on fixed blade cas-

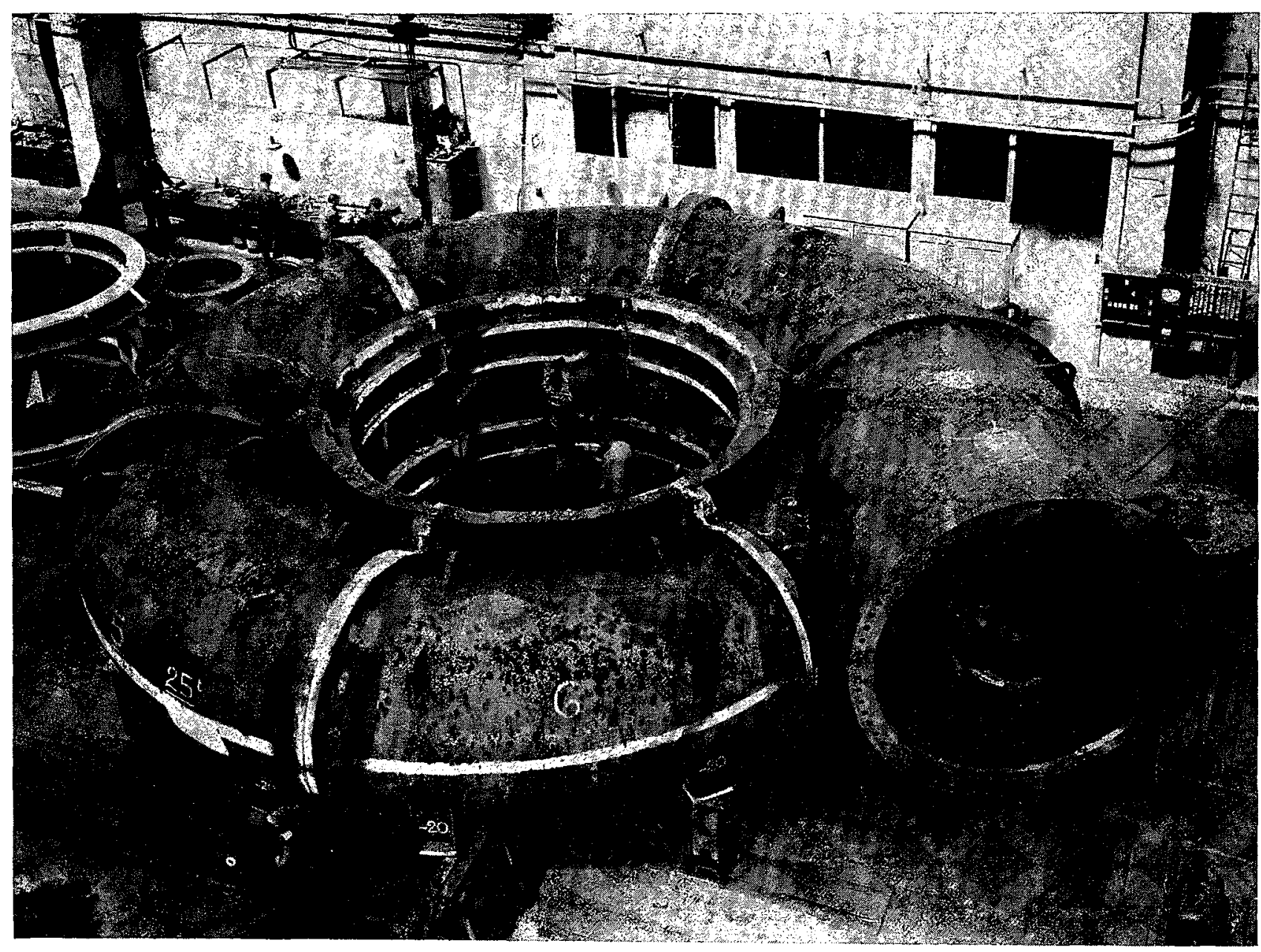

Fig. 11

(Cliché Neyrpic.)

Sariyar (Turquie) 2 turbines Francis à axe vertical.

Puissance : $65000 \mathrm{~kW}$. Chute : $93 \mathrm{~m}$. Vitesse : $187 \mathrm{tr} / \mathrm{mn}$.

Montage d'une bâche en acier moulé en six parties.

Sariyar, Turkey. Tivo vertical-shaft Francis turbines. Output: $65,000 \mathrm{~kW}$. Head: $93 \mathrm{~m}$. Speed: 187 r.p.m. Assembling a six-piece cast steel spiral casing. 
ratoire, les recherches sur le maximum possible des angles d'incidence de l'écoulement sur les aubages fixes de l'avant-distributeur, ont permis de réduire sensiblement les diamètres d'enroulement des bâches.

D'autre part, les sections transversales ont été également diminuées en augmentant les vitesses d'entrée de l'eau dans la bâche, ceci sans réduction des rendements car, avec l'augmentation des puissances unitaires, donc des dimensions absolues, l'effet de rugosité relative et partant, les pertes par frottement, ont moins d'importance.

Les dimensions, en plan, étant réduites, il fallait ensuite, pour continuer de gagner du poids, diminuer les épaisseurs, ce qui a été permis par l'amélioration considérable des méthodes de calcul.

Au sujet des épaisseurs à prendre en compte, je pense qu'un intéressant sujet de débats se posera dans les années à venir : c'est le choix de la pression d'essai des bâches.

On a coutume de les essayer à une fois et demie la pression de service, c'est-à-dire la pression statique plus la surpression la plus dangereuse. Celle-ci atteint habituellement $30 \%$ de la chute nette. Ceci conduit a une pression d'essai égale à deux fois la chute nette. Or les bâches sont essayées, en atelier ou sur le site, dans des conditions bien différentes de celles qu'elles supportent en service, c'est-à-dire sans les flasques qui les rigidifient, et surtout sans tenir compte du béton qui interviendra dans la résistance de l'ensemble, comme il intervient dans une conduite forcée constituée par un blindage en acier, logé dans le rocher avec bourrage d'e béton.

On peut se demander s'il est bien raisonnable de pousser aussi loin cet essai qui, évidemment, fatigue le matériel et si un peu plu's de hardiesse n'irait pas dans le sens de l'économie. De plus, toutes les sociétés ne suivent pas les mêmes normes et c'est ce qui rend souvent les comparaisons de prix très difficiles; il est tout à fait différent de pratiquer un essai d'étanchéité sous $130 \mathrm{~m}$, pour une pression nette de $100 \mathrm{~m}$, ou d'essayer une bâche sous $1,5 \times 130$ $=195 \mathrm{~m}$.

Un des facteurs d'allègement des bâches a été la prédominance de la construction soudée sur la construction moulée. Les bâches en acier moulé (fig. 11) ont cédé le pas aux bâches mixtes, avec avant-distributeur en acier moulé, volute en soudé, puis on est passé à la construction entièrement soudée. Les domaines d'emploi des trois types de construction ont varié au cours de ces dernières années, toujours du reste en faveur de la construction entièrement soudée (fig. 12). La construction moulée est ré- cades, the visual observation of flows in the laboratory, and the determination of maximum possible angles of flow incidence on the stay vanes (Fig. 11).

Sinaller spiral casing cross-sections have been achieved by increasing the flow velocities at the spiral casing intake. This has been done without involving any loss of efficiency, for now that turbine outputs and absolute dimensions have increased, relative roughness effects (i.e. frictional losses) have lost much of their former importance.

After reducing the plan dimensions of spiral casings, the next step was to try to also reduce the thickness of their walls, which was successfully achieved thanks to considerable improvements in the relevant design methods.

Whilst on the subject of wall thickness, I cannot help feeling that spiral casing test pressures are likely to give rise to some interesting discussions before long. The test pressure usually applied is equivalent to about one and a half times the service pressure, in other words the static pressure plus the most dangerous pressure peak, which latter normally amounts to $30 \%$ of the net head. 'Thus, the test pressure is equivalent to twice the net head.

The conditions under which spiral casings are tested at the factory or on the site are very different from those they will undergo in service, as they are tested without the distributor rings which normally help to stiffen them and, above all, without allowing for the concretework, which adds to the strength of the assembly much in the same way as in a steel sheeting penstock in a concrete-lined rock shaft.

The necessity of carrying out this test under such very severe conditions is a question open to some doubt, because of the strain to which the material is subjected, and there seem to be grounds for wondering whether a somewhat bolder approach aimed at increased economy would not be more rewarding. In addition, as the standards laid down by various manufacturers differ, price comparisons are often very difficult. A leakage test on a spiral casing under a head of $130 \mathrm{~m}$ for a net pressure of $100 \mathrm{~m}$, and one carried out under $1.5 \times 130$ $=195 \mathrm{~m}$, are two very different matters indeed.

The development of welded constructions to replace castings has been a major component weight reducing factor. Cast steel casings (Fig. 11) first gave way to composite designs featuring cast-steel stay vane assemblies and a welded plate spiral casing, but these, in turn, were superseded by all-welded assemblies. The applications of these three types of design have varied during the last few years, but the main 


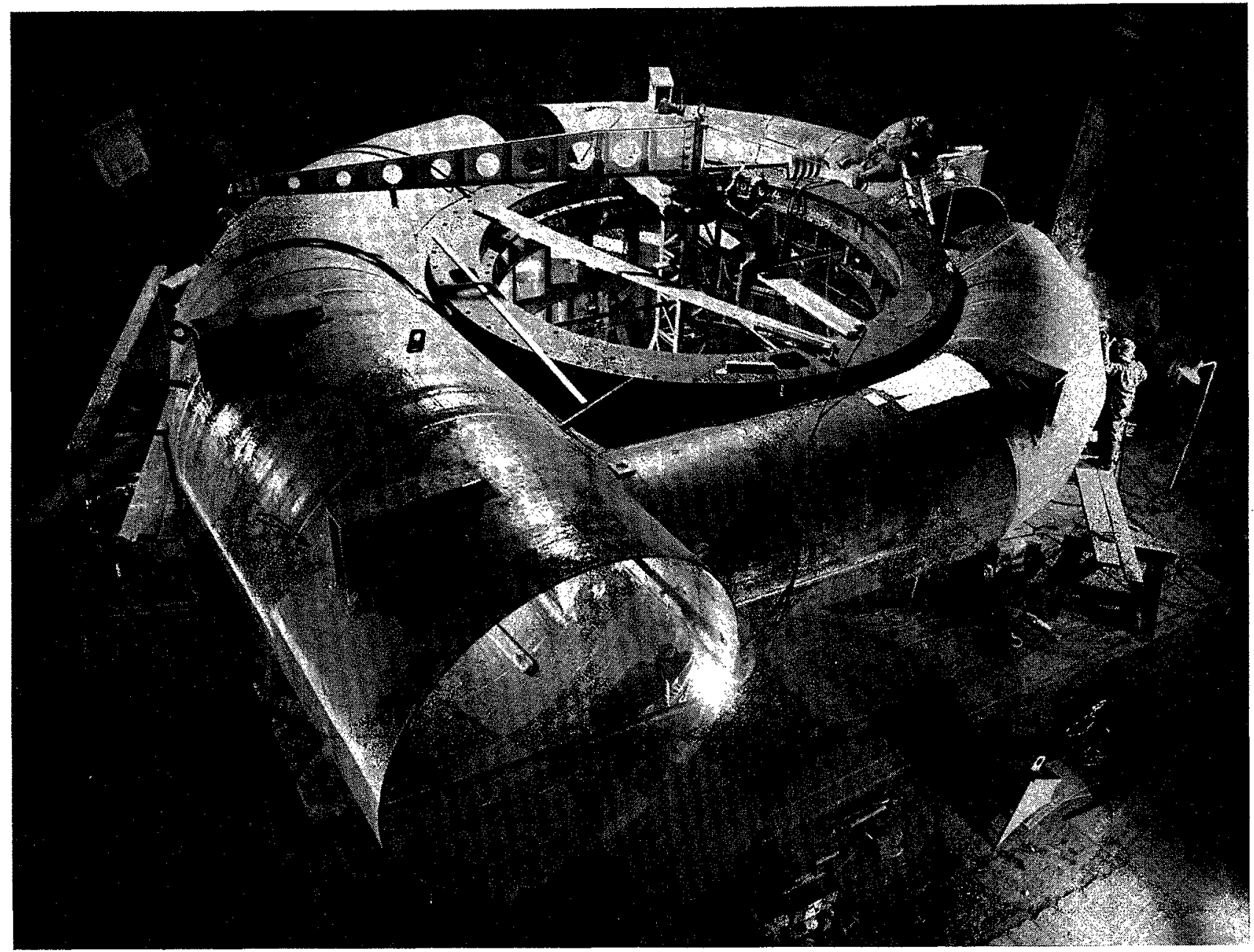

FIG. 12

(Cliché Neyrpic.)

Monteynard (caractéristiques : voir fig. 9). Construction d'une bàche en tôle soudée.

Monteynard (characteristics: see Fig. 9). Assembling a welded-plate spiral casing.

servée aux turbines de haute chute, les avantdistributeurs moulés avec volutes soudées plutôt aux machines moyennes; les très grandes machines sont entièrement à base de construction en tôle soudée (fig. 13).

On peut se demander si les constructeurs n'ont pas été trop loin et trop vite, car la construction entièrement soudée demande des tôles de haute qualité, donc chères, des procédés de soudage très au point, des contrôles fréquents avec recuits entre opérations, finalement des temps d'exécution très longs, et la comparaison des prix de revient n'est pas aussi favorable qu'on aurait pu le croire. Il est possible que, dans certains cas, la technique soit à revoir.

On a essayé d'aller plus loin, particulièrement en Amérique et maintenant en Europe, avec l'emploi d'acier à très haute résistance du type TI. Il paraît prudent d'attendre pour tirer des conclusions, car le prix des aciers spéciaux trend has invariably been in favour of the allwelded type of construction (Fig. 12). Cast designs are reserved for turbines working under a very high head, whilst composite constructions are mainly used for medium machines. Very big turbines are based entirely on the allwelded type of construction (Fig. 13).

One is entitled to wonder whether the allwelded type of design has not been developed in too much of a hurry and too far, for it requires very expensive high-quality steels, very advanced welding methods, frequent inspections with annealing between each operation, and very manufacturing times. It may, therefore, turn out to be less favourable from the comparative cost point of view than was originally believed, and the technique involved may well have to be reviewed in certain cases.

Attempts have been made-first in America, and then in Europe-to use type TI very high 
est tel qu'il n'est pas prouvé que ce mode de construction soit tellement économique par rapport à ceux employés jusqu'alors.

\section{LES DISTRIBUTEURS}

Les flasques, autrefois toujours en acier moulé, sont exécutés en construction mécanosoudée (fig. 13).

Je désirerais attirer l'attention sur les plaques d'usure, placées au-dessus et au-dessous des directrices. Elles sont presque toujours demandées en acier inoxydable. Or, il n'y a pas de cavitation dans cette région de l'écoulement; le seul problème est l'usure par les sables et un acier dur à haute résistance, beaucoup plus éco- tensile steel for all-welded constructions. It would no doubt be rather unwise jump to any conclusions at this stage, for in view of the high cost of these special steels, it is by no means certain that this type of construction is really very much cheaper than more conventional designs.

\section{Guide VANE ASSEMbliEs.}

The distributor rings invariably used to be steel castings, but are now being made as mechanically welded components (Fig. 13).

I feel a word or two should be said about the wearing plates at either end of the suide vanes, which are almost invariably required to

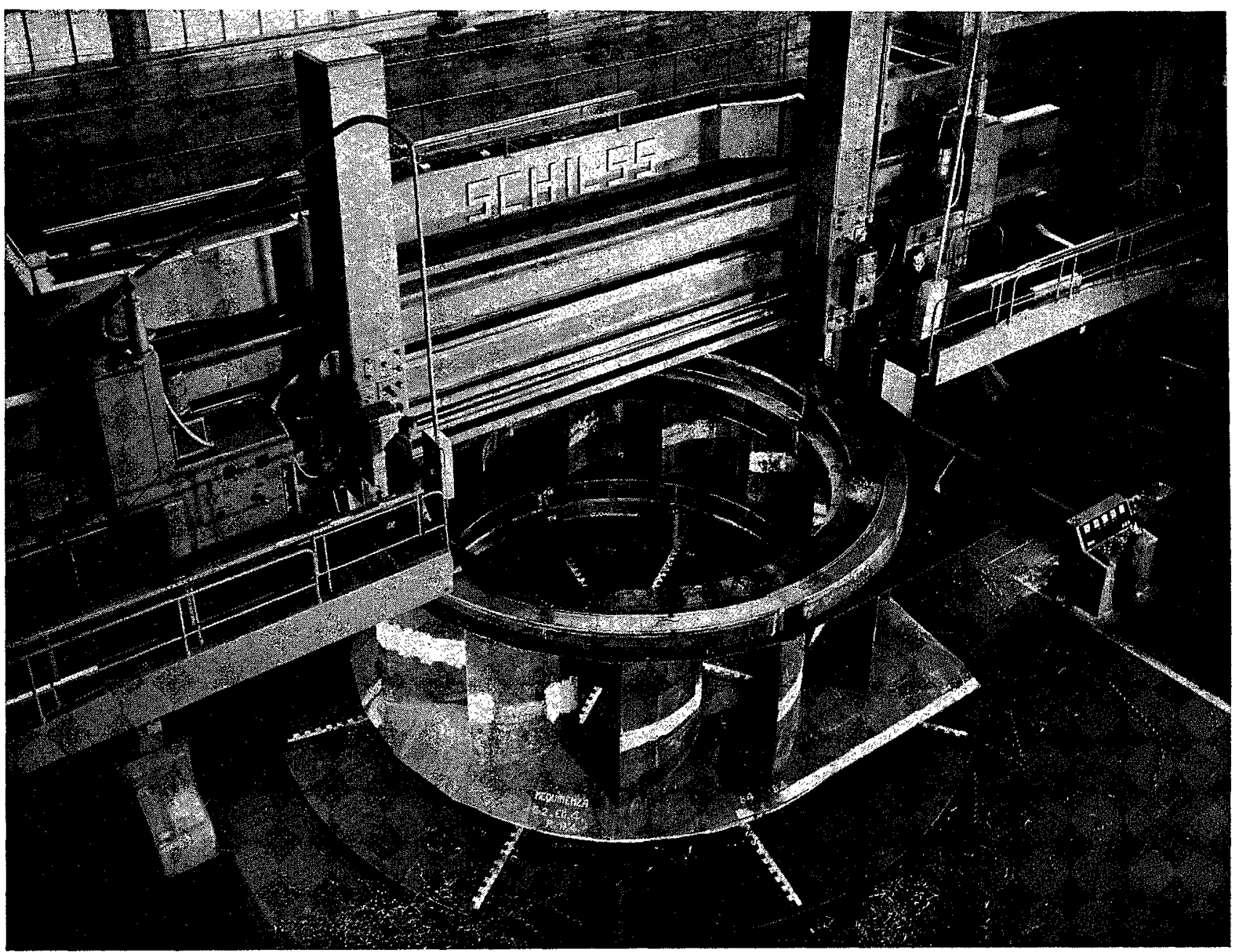

FIG. 13

Mequinenza (Espagne). 4 turbines Francis à axe vertical.

Puissance : $80200 \mathrm{~kW}$. Chute : $62 \mathrm{~m}$. Vitesse $: 136,5 \mathrm{tr} / \mathrm{mn}$. Diamètre de roue $: 4300 \mathrm{~mm}$. Usinage d'un avant-distributeur sur un tour vertical de $12 \mathrm{~m}$ de diamètre.

Mequinenza, Spain. Four vertical-shaft Francis turbines.

Output: $80,200 \mathrm{~kW}$. Head: $62^{\mathrm{e}} \mathrm{m}$. Speed: 136.5 r.p.m. Runner diameter: $4,300 \mathrm{~mm}$. Machining a stay-vane assembly on a vertical lathe. 
nomique, suffirait largement. La construction de ces plaques en acier inoxydable est extrêmement onéreuse, qu'on les découpe dans des tôles ou qu'on les obtienne à partir de pièces moulées. Il en est de même pour les labyrinthes fixes.

Le réglage des distributeur's a été amélioré, surtout pour les turbines de hante chute où les jeux entre directrices et plaques d'usure sont très faibles - de l'ordre de $2 / 10^{\text {es }}$ de millimètre, quelquefois moins.

Pour la mancuvre du vannage et pour les machines de très grandes dimensions, on a pensé, aussi bien en Russie qu'en Europe à remplacer les deux servo-moteurs de manœuvre et le cercle de vannage par des servomoteurs individuels, chaque servo-moteur étant accouplé à une directrice et un système de biellettes de synchronisation reliant les directrices entre elles.

Enfin, des réalisations sont en cours, notamment en France, pour remplacer les douilles en bronze des directrices par des douilles en téflon, qu'il n'est pas nécessaire de graisser. Ceci nécessite le chromage dur des tourillons de directrices, qui ne va pas sans difficulté. C'est une solution qui facilite l'entretien en supprimant le graissage, mais son prix est assez élevé. Le téflon s'emploie en bandes enroulées autour du tourillon de la directrice ou bien en douilles composites formées de téflon imprégné dans un métal fritlé. De la même manière, pour les cercles de vannage, des supports de glissement constitués par un métal ne nécessitant pas de graissage ont été utilisés. Il s'agit de plaquettes en bronze auto-lubrifiant, imprégnées d'huile sous vide; quand la pièce tournante se met en mouvement, le graissage s'effectue.

\section{LES TURES D'ASPIRATTON}

Ces tubes d'aspiration sont soumis à des pressions et des vitesses d'écoulement très acceptables dans les conditions de marche normale, mais, dans certains régimes transitoires ou dans certains fonctionnements à charges partielles, les fluctuations de pression et les changements brusques en vitesse et en direction de l'écoulement entraînent des perturbations. Si la chute varie beaucoup, la zone dangereuse ctant toujours celle des basses chutes, il devient utile de blinder l'aspirateur. Par contre, si elle varie peu, c'est inutile.

\section{VARIATIONS DE PRESSION}

J'en viens à parler d'une question d'actualité, celle de l'aération dans les turbines Francis (fig. 14).

Lorsqu'une turbine est appelée à fonctionner sous une gamme de chutes étendue et à des ouvertures plus petites que celles placées sur la be of stainless steel. As no cavitation occurs in this flow region, however, and as the only problem is how to deal with wear due to sand in the water, a hard-wearing steel would not only be largely adequate for the purpose, but also much less expensive. Both fabricated and cast stainless steel wearing plates are extremely costly, items, and so, incidentally, are the fixed labyrinths.

Much more accurate guide vane settings have also been achieved, especially in high-head turbines, where the clearances between vanes and wearing plates have been reduced to as little as about $0.2 \mathrm{~mm}$, and sometimes even less.

As regards guide vane control systems for very powerful turbines, both Russian and European designers have been working on the idea of replacing the twin servomotor and distributor ring layout by a system in which each guide vane has its own servomotor, the individual guide vanes being interconnected by synchronisation links.

A further development-especially in France - has been to replace the conventional bronze guide vane bushes by Teflon components which do not require any lubrication. With this type of bush, however, the guide vane stems have to be hard chromium plated, which is by no means a simple operation. Furthermore, this is a rather expansive type of design, though its lack of lubrication requirements is, on the other hand a very attractive feature. The Teflon bearing either takes the form of strips of the material which are wrapped round the guide vane stem, or of composite bushes made of Teflon impregnated with a sintered metal. Similarly, gate ring slide bearings have been made of a self-lubricating bronze impregnated with oil under a vacuum, so that it Iubricates the gate operating ring as soon as the latter begins to turn.

\section{Draught tubes.}

Francis turbine draught tubes operate under quite acceptable pressures and flow velocities under normal running conditions, but under certain transient conditions, or sometimes when the turbine is running under a partial load, disturbances are caused by pressure fluctuations and sudden changes is flow velocity and direction. Where the head varies over a wide range, the low head range is invariably the dangerous one, and it is then advisable to provide the draught tube with sheeting. Sheeting can be dispensed with if the head variation range is only small.

Pressure variations.

We shall now discuss the very topical question of aeration in Francis turbines 


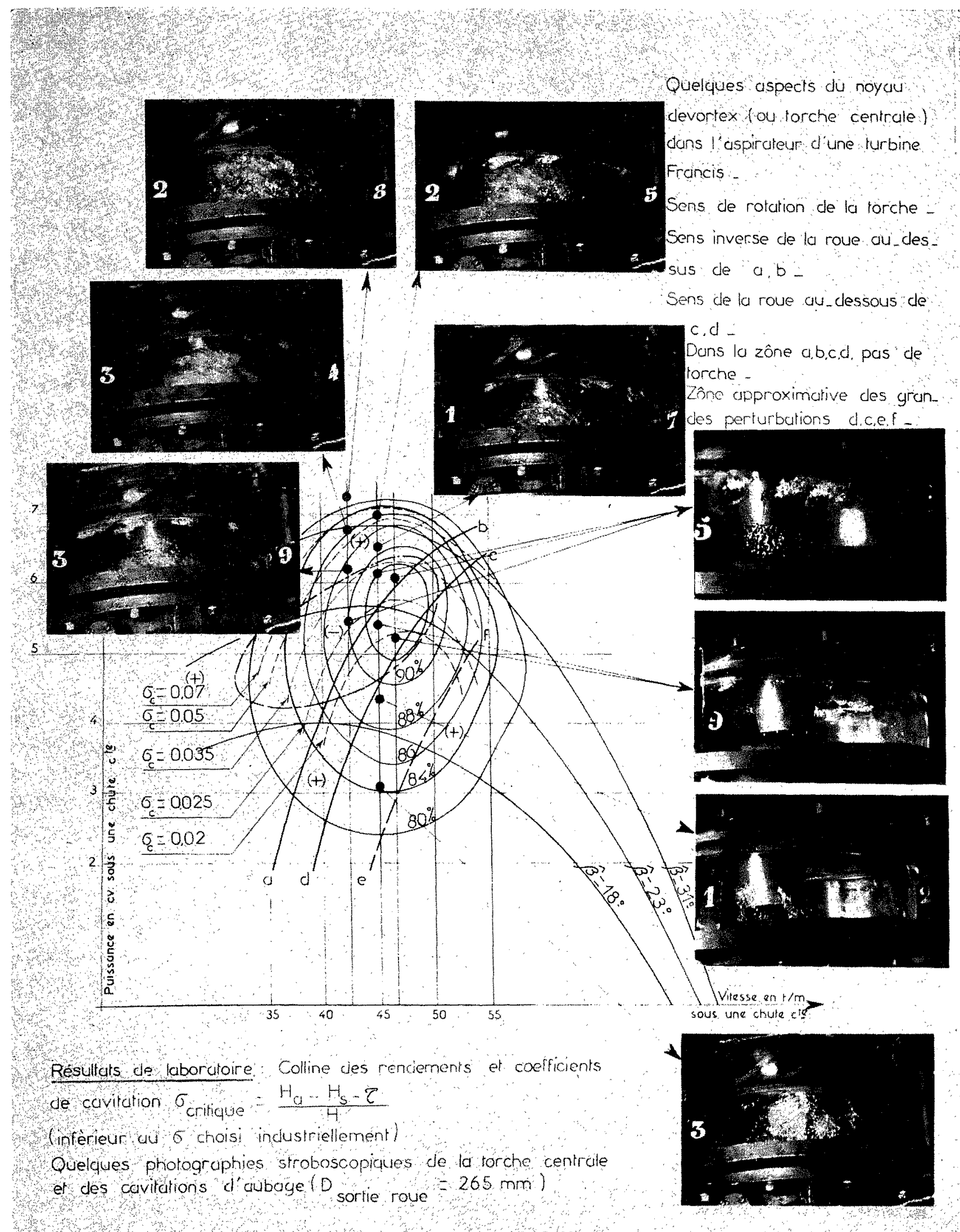

FIG. 14

(Cliches Neyrpic.)

Colline des rendements et coefficients de cavitation ainsi que quelques photographies stroboscopiques de la torche centrale et des cavitations d'aubage.

Turbine efficiency curves and cavitation coefficients, with stroboscopic views of the runner cone vortex and blade cavitation. 
colline d'essais en dessous d'une zone dite « stable », déterminée expérimentalement dans chaque cas, l'eau quitte la roue en tournant, dans l'aspirateur, dans le même sens que la roue. Au voisinage de l'axe de la turbine, la pression diminue jusqu'à la valeur de la tension de vapeur, il se produit alors brutalement une intense vaporisation qui entraine une perturbation de pression considérable. Cette fluctuation se répercute dans tout l'écoulement, depuis l'aspirateur jusqu’à la conduite forcée. La zone en dépression, qui prend naissance à la pointe de roue, présente la forme générale d'un tire-bouchon. La résorption de vapeur, accompagnée de crépitements, peut être périodique ou intermittente. Elle entraîne, même à distributeur fixe, des variations de puissance et de vitesse de la turbine, et, dans certains cas, les oscillations de pression provoquent des variations importantes de la poussée sur la pivoterie.

Les principales solutions employées pour remédier à ce phénomène sont les suivantes :

- l'aération naturelle au travers du fond de la turbine;

- l'aération par l'axe de la turbine;

- un tripode fixé sous la roue, muni de trous judicieusement placés dans les zones de dépression maximale.

On a aussi essayé des dièdres stabilisateurs dans lesquels on injecte de l'air, ces dièdres étant fixés sur le cône à la sortie de la roue et combinés, par exemple, avec une aération axiale.

Enfin on a employé un compresseur auxiliaire, quand l'air ne peut pénétrer à la pression atmosphérique, la roue étant en dessous du niveau aval.

Tous ces palliatifs ont été utilisés avec succès, quelquefois plusieurs à la fois, et il n'y a pas encore une doctrine vraiment établie à ce sujet. C'est l'une des études les plus intéressantes de l'heure actuelle.

\section{LES ROUES}

Leur poids a augmenté avec les puissances unitaires. Celles de Chastang pesaient déjà $42 \mathrm{t}$ en 1947. Celles d'Infiernillo, $53 \mathrm{t}$ (fig. 15). Il a été réalisé des roues en un seul élément de $70 \mathrm{t}$ à $80 \mathrm{t}$. Pour obtenir une roue d'un poids final de $53 \mathrm{t}$, il faut couler en aciérie $80 \mathrm{t}$. L'équipement des aciéries devient insuffisant pour les couler d'une pièce. Par ailleurs, les difficultés de transport deviennent sérieuses.

C'est ce qui a conduit aux roues en plusieurs pièces, malgré la complication réelle qui en résulte. Cette conception ne présente évidemment un intérêt que pour les grandes puissances et pour les vitesses spécifiques élevées. Pour
Where a turbine has to operate under a wide range of different heads and at openings than below the 'stable' region of the turbine characteristics-which latter is determined experimentally in each case-a swirl in the direction of runner rotation is imparted to the flow in the draught tube, as a result of which pressures near the turbine shaft fall to the vapour pressure level, giving rise to a sudden occurrence of intensive vapour formation which seriously upsets the pressure pattern. This fluctuation affects the entire flow from the draught tube all the way back to the penstock. The depression area originating at the runner tip is rather like a corkscrew in shape; vapour resorption may either be periodic or intermittent, and is accompanied by a crackling noise. Even with a fixed guide vane assembly, it causes turbine power and speed variations, and in some cases, these pressure oscillations are liable to cause considerable fluctuations of the loads acting on the thrust bearing.

The following are the main preventive measures which have been used or tried out for this condition:

(i) Natural aeration through the turbine head cover;

(ii) Aeration through the turbine shaft;

(iii) Aeration by means of a tripod mounted underneath the runner, with holes positionned in the areas of maximum depression;

(iv) Stabilisers in the form of dihedral plates fitted to the runner exit cone and into which air is injected. These may also be combined with axial aeration;

(v) Air injection by means of an auxiliary compressor where air cannot be injected under atmospheric pressure because the runner is set below the downstream water level.

Successful results have been obtained with all these methods, or sometimes with several of them combined. No standard practice has so far been established, and the question is one of the most interesting subjects of present-day research in this connection.

\section{RUNNERS.}

Runner weights have increased with individual outputs. The runners which were installed at Chastang in 1947 already weighed 42 tons, and those in the recent Infiernillo project weigh 53 tons (Fig. 15). Runners weighing from 70 tons to 80 tons have also been produced in one piece. In view of the fact that the production of a finished 52 tons runner involves the casting of some 80 tons of metal, present foundry facilities are rapidly becoming insufficient for the production of such large 
les petites vitesses spécifiques, c'est-à-dire les hautes chutes, les diamètres sont toujours inférieurs à $3,50 \mathrm{~m}$.

Voici quelques solutions de roues composées:

- roues en deux pièces avec assemblage au plafond et à la ceinture, les deux moitiés étant maintenues ensemble par clavettes emmanchées à force; des chevilles cylindriques assurent le repérage; les cercles d'usure, en une seule pièce, complètent le dispositif d'assemblage;

- roues en trois pièces, avec brides boulonnées et coupes radiales sur le plafond (en components in a single piece, added to which serious transport problems are also having to be dealt with.

This has led to the practice of building runners out of several individual components, despite the difficulties involved, a method which can, however, obviously only be of interest for high-output and high specific speed units. Runner diameters for low specific speeds-i.e. high heads-are invariably less than $3.5 \mathrm{~m}$.

The following are a few examples of composite runner designs:

(i) Two-piece runners joined at the runner

Fig. 15

Infiernillo (Mexique). 4 turbines Francis à axe vertical. Puissance : $173000 \mathrm{~kW}$. Chute : $101 \mathrm{~m}$.

Vitesse : $136,4 \mathrm{tr} / \mathrm{mn}$. Roue brute de fonderie.

Infiernillo, Mexico. Four vertical-shaft Francis turbines. Output: $173,000 \mathrm{~kW}$ Head: $101 \mathrm{~m}$

Speed: 136.4 r.p.m. A newly-cast runner.

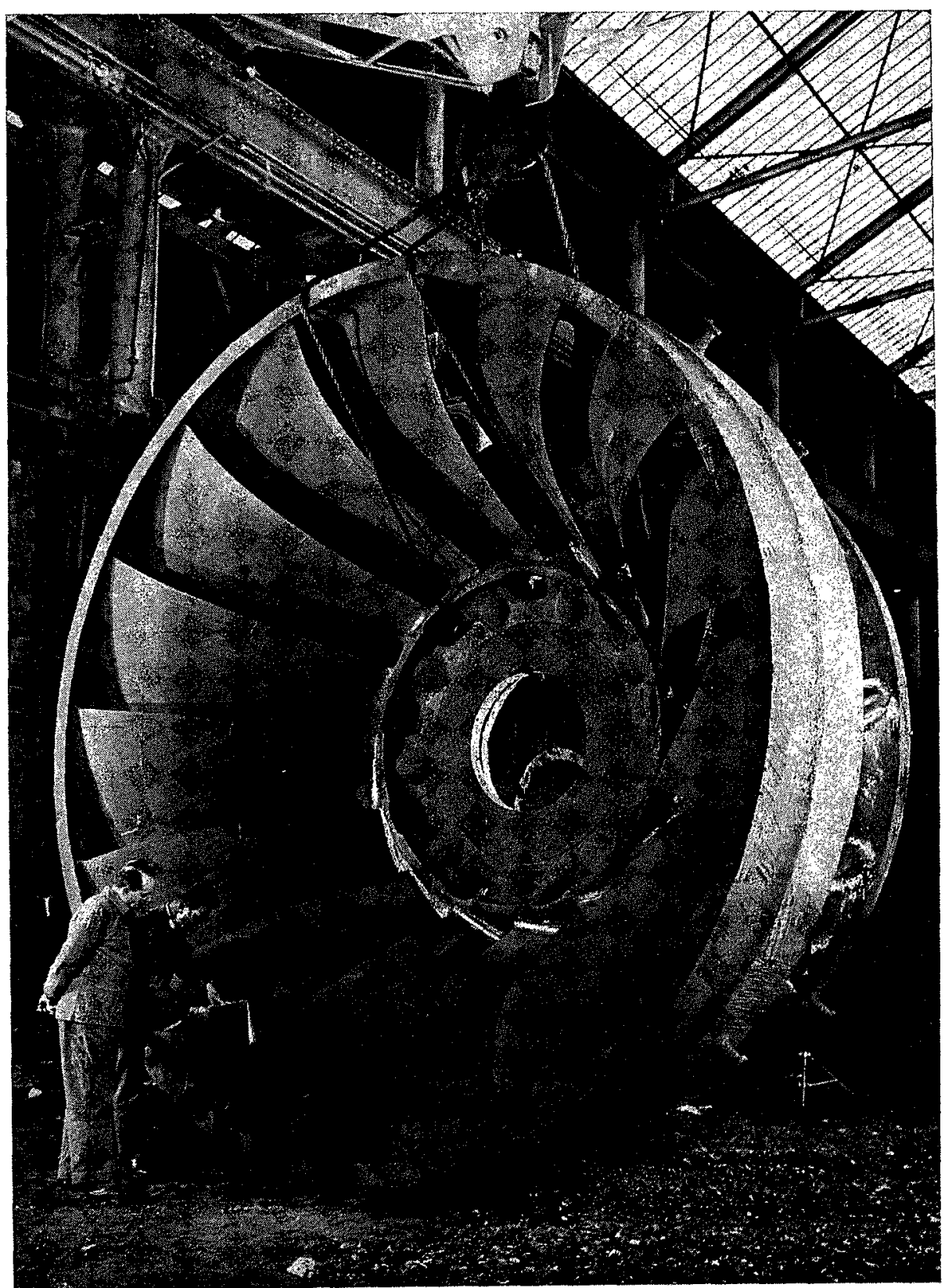


Amérique pour roues de plus de $100 \mathrm{t}$ ); - morceaux de roues comportant chacun quatre ou cinq aubes, plus un moyeu central, plus des anneaux de frettage (en Amérique pour des roues de $140 \mathrm{t}$ );

- autre solution :-un plafond, une ceinture et des aubes soudées à la fois sur le plafond et sur la ceinture. Cette technique permet l'assemblage d'éléments constitués par des métaux différents, les aubes étant en acier inoxydable, le plafond et la ceinture en acier ordinaire. C'est une technique difficile : pendant le soudage, il faut prendre de très grandes précautions pour éviter des déformations et des fissures; la préparation de chaque pièce est très certainement longue et coûteuse; il faut préréchauffer et recuire en cours de fabrication. C'est cependant la voie ou nous serons amenés dans l'avenir avec l'augmentation des puissances.

Pour en rester aux dimensions actuelles, on hésite quelquefois entre les roues exécutées entièrement en acier inoxydable, et les roues en acier au carbone plaquées d'acier inoxyciable dans les zones soumises à la cavitation.

La visualisation sur modèle réduit des phénomènes de cavitation a permis de localiser, avec bien plus de précision que par le passé, les zones où la cavitation a la chance d'apparaître; de même l'examen suivi des roues industrielles.

C'est ce qui a permis de généraliser les roues en acier au carbone, beaucoup plus économiques, avec placage en acier inoxydable (18\% de $\mathrm{Ni}-8 \%$ de $\mathrm{Cr}$ ) des parties qui peurent craindre la cavitation.

Le placage n'est applicable que si les canaux des aubages sont accessibles, c'est-à-dire lorsque la roue est de dimensions suffisantes.

Il est aussi efficace, sinon meilleur, que les roues monoblocs en acier inoxydable à $13 \%$ de chrome, car le métal d'apport (en 18-8) présente une bien meilleure résistance à la cavitation que l'acier à $13 \%$ de chrome.

\section{LES PIVOTS}

Le bon fonctionnement d'une pivoterie est lié à la formation et au maintien d'un film d'huile entre patin et grain mobile. Ce film est tributaire des conditions thermiques dans lescutelles les pièces travaillent, de leur orientation relative en cours de fonctionnement, done de la répartition des charges sur les patins, répartition qui doit être uniforme, et enfin du mode d'usinage. Le mouvement relatif des pièces en contact peut être très lent au démarrage et à l'arrêt du groupe, ce qui risque d'entraîner la rupture du film d'huile. crown and runmer band, both halves being held together by pins which are in interference fit in their holes; correct alignment is ensured by dowels. The assembly is completed by wearing rings made in one piece;

(ii) Three-piece runners with bolted flanges and radial joints in the runner crown (In America, this method is used for runners weighing over 100 tons);

(iii) Runners made up of individual sections with four or five blades each, the assembly being held together by shrunk-on hoops (used in America for runners weighing over 140 tons);

(iv) Runners consisting of a runner crown, a runner band, and blades welded to both components. Different metals can be used together in this type of construction, such as stainless steel blades and ordinary mild steel for the runner band and crown for instance. This type of assembly is difficult to build because of the care required to prevent deformation and cracking and the amount of time it takes to manufacture each part; repeated preheating and annealing operations are necessary throughout the manufacturing process. And yet, this is the method which will have to be used more and more in future as turbine outputs increase.

In the current rumner-size range, the problem occasionally arises of having to choose between stainless steel throughout and ordinary mild steel plated with stainless steel in areas affected by cavitation. With the modern visual observation methods used in scale model research, likely cavitation areas are identified much more easily than in the past, and it is a simple matter to follow the behaviour of industrial runners on a continuous basis. As a result, carbon steel runners with $18 \%$ nickel, $8 \%$ chrome stainless steel plating in areas exposed to cavitation has come into more general use. However, plating is only possible if the blading channels are accessible, that is to say if the runner is sufficiently big. A plated runner is just as effective-if not more so- than one made entirely of $13 \%$ chrome stainless steel, as the plating material offers a much better resistance to cavitation.

\section{'THRUST BEARINGS.}

Satisfactory thrust bearing operation depends on the formation and maintaining of an oil film between the bearing pads and thrust collar. This film in turn depends on the component working temperatures, their respective positions during operation (and hence the load distribution on the pads, which should be uniform), and componnent finish. The relative movement between individual components may be very slow' when the turbine is starting and stopping 
Nous trouvons actuellement plusieurs conceptions de pivoteries.

Pour les pivots qui supportent une charge inférieure à 800 à $1000 \mathrm{t}$, nous pensons que le pivot à colonnettes, d'une grande simplicité, monobloc, présente une sécurité totale. Il peut supporter des charges spécifiques élevées et il est, de loin, le plus économique (fig. 16).

Au-delà de 800 à $1000 \mathrm{t}$, les pivots à patins indépendants s'imposent. En effet, il apparaît and may cause the oil film to break down. Thrust bearings are used in the following different form:

(i) Bearings with rigidly-mounted pads for loads of up to 800 tons to 1,000 tons. These unit-construction components are extremely reliable, can take high specific loads, and are by far the least expensive (Fig. 16);

(ii) Bearings with independently mounted pads for loads in the 800 ton to 1,000 ton range,

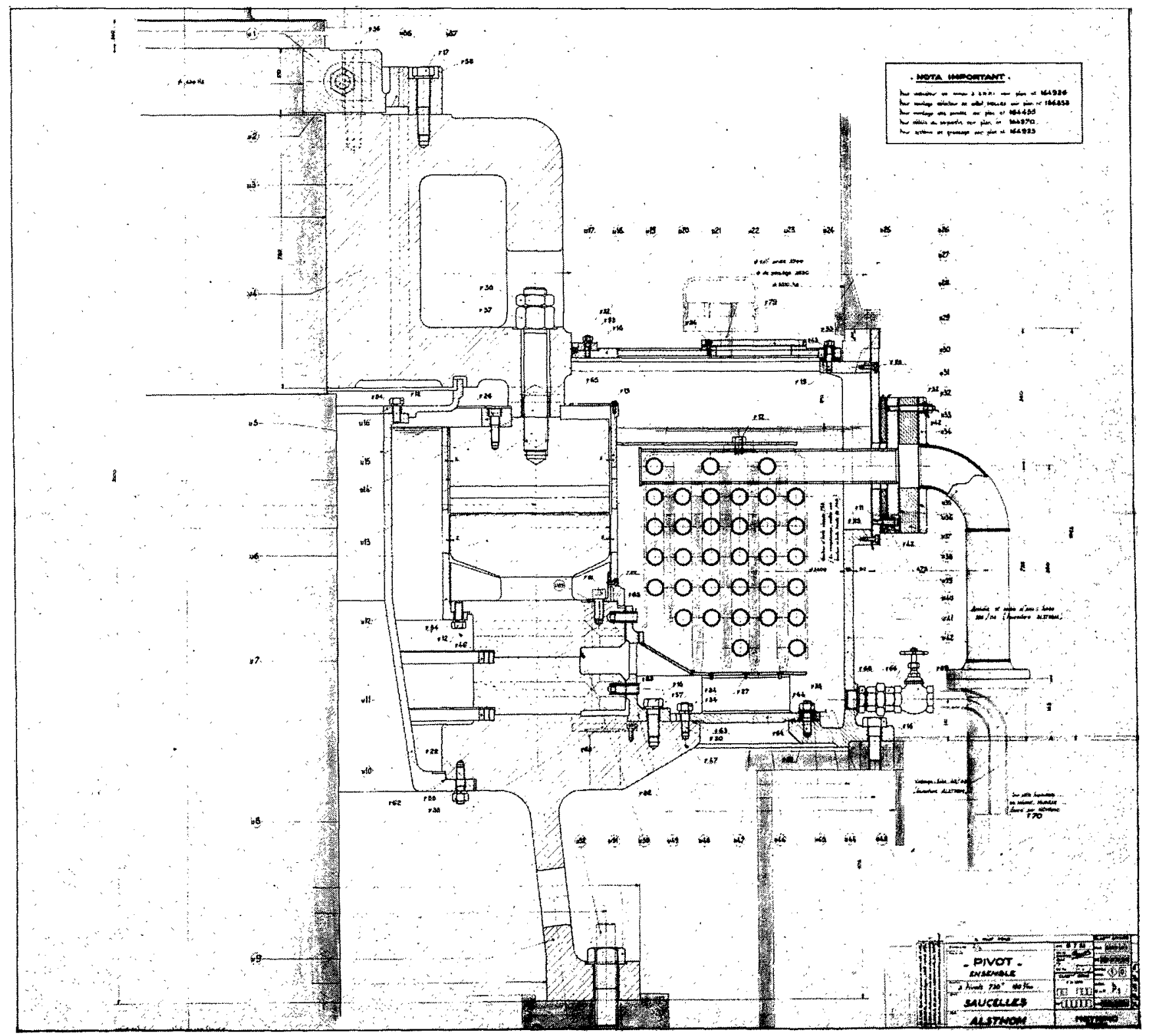

FIG. 16

Saucelles (Espagne). 4 piyots à patins fléchissants. Charge : $730 \mathrm{t}$. Vitesse : $150 \mathrm{tr} / \mathrm{mn}$. Coupe d'un pivot.

Saucelles, Spain. Four flexible-pad thrust bearings.

Head: 730 tons. Speed. 150 r.p.m. Cross-sectional view of a thrust bearing. 
alors des problèmes de déformation thermique. Les déformations mécaniques doivent être limitées à des valeurs acceptables et des solutions ont été apportées.

Dans l'une d'elles, on mesure, à l'arrêt, les charges sur chacun des patins et on essaie de les rendre identiques (fig. 17). Pour cela, chaque patin repose sur un disque flexible comportant une rotule; les rotules s'appuient sur une couronne qui transmet les charges au support du pivot par l'intermédiaire de cales planes. La mesure de la flèche du disque d'appui des patins permet un contrôle de la répartition des charges; pour la corriger: on modifie l'épaisseur des cales d'appui. Ceci a été réalisé pour des turbines de $115000 \mathrm{ch}$ sous $130 \mathrm{~m}$ de chute (Monteynard).

Dans le deuxième système, dit « auto-compensé », chaque patin est fixé sur une membrane torique en acier de faible épaisseur et très flexible (fig. 18). Ces membranes sont fixées sur une couronne d'appui qui transmet les charges. Des conduits percés dans cette couronne mettent en communication les enceintes étanahes constituées par les membranes toriques; l'ensemble du volume limité par les membranes et les canalisations de la plaque d'appui est rempli d'huile. La pression régnant dans chacune des membranes toriques étant identique, on obtient ainsi une équirépartition quasi parfaite. C'est le système que nous avons employé pour les pivots d'Infiernillo qui supportent $1050 \mathrm{t}$.

\section{LES ORGanes DE GARDE}

Dans beaucoup d'aménagements qui disposent d'une conduite forcée par groupe, les organes de garde ont été supprimés. Pour les Francis c'étaient le plus souvent des papillons, les sphériques étant réservés aux chutes dépassant 180 à $200 \mathrm{~m}$. En plus de l'économie sur le matériel, ceci permet de réduire la largeur de la centrale et la portée du pont-roulant.

Pour remplacer les papillons, différentes solutions ont été essayées.

D'abord le distributeur étanche. Sur une machine prototype de $17000 \mathrm{ch}$ sous $120 \mathrm{~m}$ de chute l'étanchéité latérale du distributeur, entre les plaques d'usure et les flancs des directrices, est obtenue par des plaquettes en bronze soigneusement ajustées. Ces plaquettes sont pressées sur les tranches supérieures et inférieures des directrices par des pièces de caoutchouc moulé qui forment à la fois ressort et étanchéité. D'autre part, des barrettes de caoutchouc sont placées verticalement le long de la ligne de contact de chacune des directrices sur la suivante et assurent l'étanchéité radiale. C'est un mode de construction assez coûteux mais qui a donné satisfaction. L'effort de vannage est aug- where high temperatures are liable to cause deformation. The mechanical strains must be kept down to acceptable values, however, which can be achieved in a number of different ways. In one system, the loads on the individual pads are measured with the turbine stationary and, as far as possible, made equal (Fig. 17). Each pad rests on a flexible dise and is provided with a swivel joint bearing against a ring which transmits the loads to the thrust bearing support via flat packing pieces. The load distribution can be determined, by measuring the amount of deflection on the flexible disc carrying the pads, and is corrected by adjusting the thickness of the packing pieces accordingly. This method has been used on 115,000 HP turbines operating under a $130 \mathrm{~m}$ head.

In an alternative layout, which is known as the 'self-compensating' system, each pad is mounted on a highly-flexible sealed thin steel capsule in the shape of a tore (Fig. 18), each capsule being fixed to a ring which transmits the bearing loads. The capsules are in communication with each other via passages in the supporting ring, which, like the capsules, are filled with oils. As the pressures inside the capsules are all the same, a practically perfect even load distribution is achieved. This system has been used in the turbines for Infiernillo, which are subjected to a load of 1,050 tons.

\section{Main ShUT-OfF Valves.}

Shut-off valves have been done away with in many projects featuring one penstock for each unit. These valves were usually of the butterfly type in the case of Francis machines, or spherical valves for heads above $180 \mathrm{~m}$ or $200 \mathrm{~m}$. In addition to reducing equipment costs, the elimination of these valves also makes it possible to build narrower power stations with reduced overhead travelling crane spans. A number of schemes have been developed in order to do away with butterfly valves, among which the following:

(i) The sealed guide vane assembly. On a prototype $17,000 \mathrm{HP}$ machine working under a $120 \mathrm{~m}$ head, lateral sealing of the guide vanes between the wearing plates and guide vane sides has been achieved by means of carefully fitted bronze plates, which are brought to bear hard up against the upper and lower guide vane sections by moulded rubber components acting as springs and seals at the same time. Vertical rubber strips are also fitted along the line of contact between each guide vane and its neighbour, so as to provide radial sealing. Though comparatively expensive, this solution has given satisfactory results. Higher guide vane operat. ing forces are required owing to the additional 


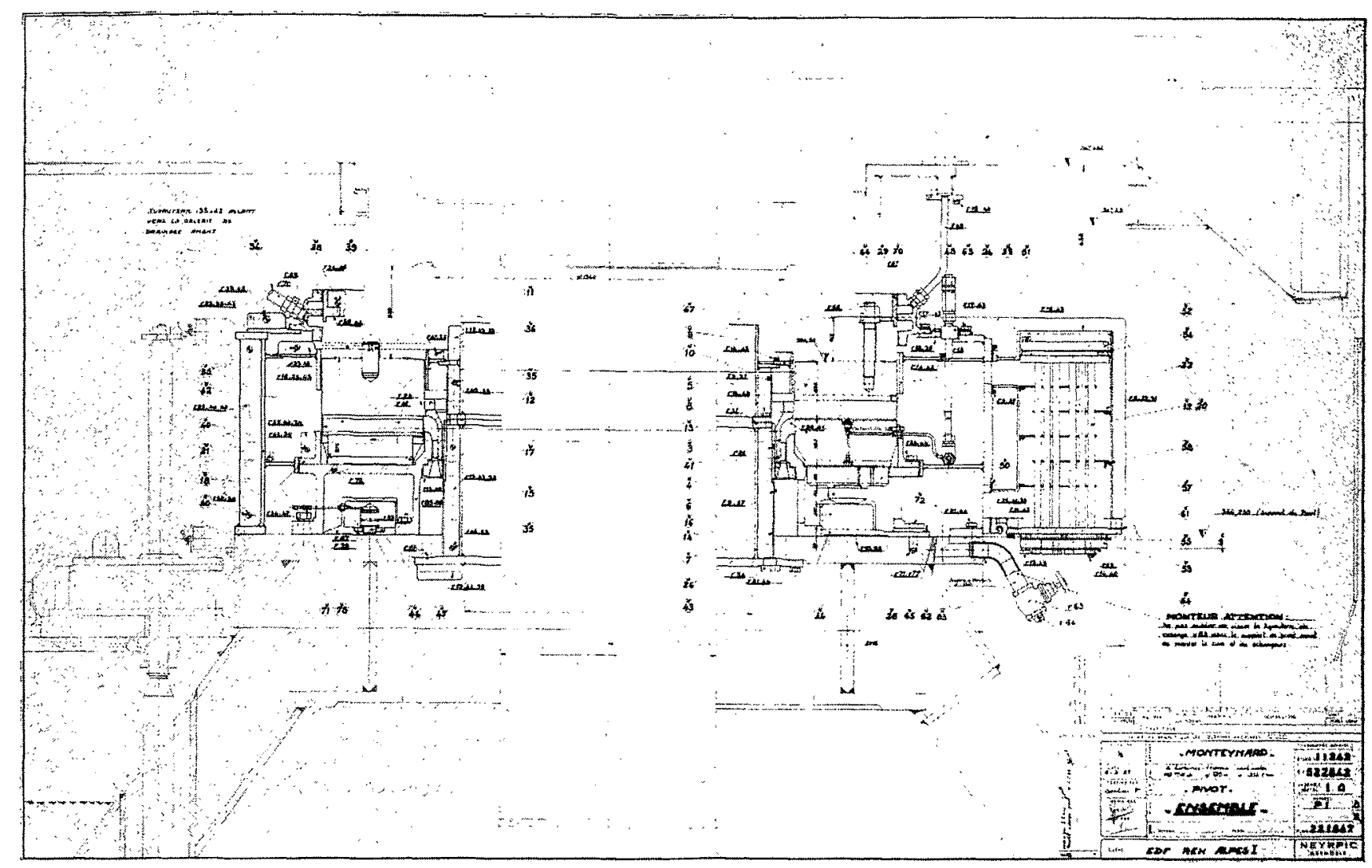

Fia. 17

Monteynard (France (caractéristiques : voir fig. 9), Coupe d'un pivot.

Monteynard, France (characteristics: see Fig. 9). Cross-sectional view of a thrust bearing.

FIG. 18

Mequinenza (Espagne) (caractéristiques : voir fig. 13). Coupe d'un pivot. Mequinenza, Spain (characteristics: see Fig. 13). Cross-sectional view of a thrust bearing.

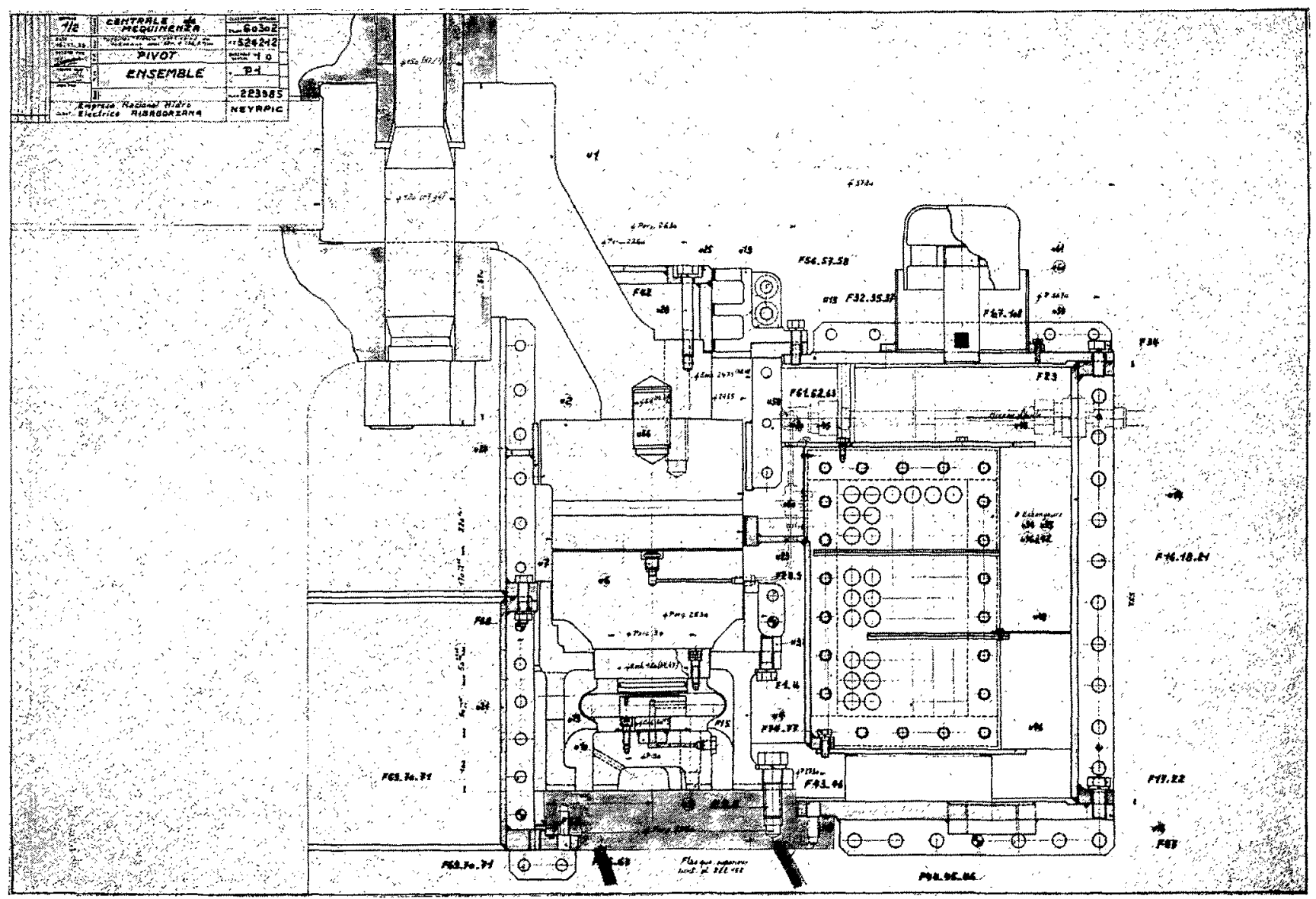


menté par les frottements supplémentaires entre directrices et plaques d'usure.

Il existe d'autres systèmes plus ou moins analogues, mais tous d'exécution relativement compliquée et chère.

Une autre solution, qui nous paraît plus élégante, consiste dans l'emploi d'une vanne cylindrique. Cette vanne est constituée par une virole, en tôle ou en acier moulé, logée dans la turbine, soit entre l'avant-distributeur et le distributeur, soit entre le distributeur et la roue. Elle porte des joints en caoutchouc sur les pourtours supérieur et inférieur qui s'appliquent, en fin de course, sur les parois latérales du distributeur. L'étanchéité est parfaite.

La commande de la vanne peut être placée soit à la partie supérieure, soit à la partie inférieure. Elle peut être soit mécanique, au moyen de vérins à vis actionnés par moteurs électriques, soit hydraulique par des servo-moteurs à huile. On a même envisagé d'utiliser l'eau de la chute pour les actionner. Il est prévu trois mécanismes de commande et la difficulté consiste à les synchroniser.

La synchronisation est assurée soit électriquement, par des selsyns agissant sur les moteurs électriques de commande des vérins, soit, dans le cas de servo-moteurs hydrauliques, par des tiroirs de distribution qui comparent, deux à deux, les positions des vérins. friction between the guide vanes and the wearing plates. Other systems have been designed along the same lines, but are all both fairly complicated and expensive to manufacture.

(ii) Cylindrical gate. This solution, which we consider to be more functional than the one just described, features a steel plate or cast steel cylindrical gate in the turbine, which is either fitted between the stay vane and guide vane assemblies or between the guide vanes and the runner. It is provided with rubber seals around its top and bottom edges which, when the gate is at the end of its travel, bear up against the guide vane support surfaces and ensure perfect watertightness.

The control system for this valve may be accommodated in the upper or the lower part of the machine. It may either be a mechanical system featuring electric motor-driven screw jacks, or a hydraulic system actuated by oil servomotors. The possibility of using available water under head in the servos has also been considered. Three control mechanisms are provided for, but the problem of synchronising them is by no means an easy one. This can be achieved either by an electrical system with selsyn-controlled jack motors or, in the case of the hydraulic servomotors, by distribution valves which 'compare' the positions of individual pairs of jacks.

\section{III. - TURBINES KAPLAN}

\section{III. - KAPLAN TURBINES}

Une grande partie des considérations exposées pour les turbines Francis s'applique aux turbines Kaplan.

\section{Augmentation de la puissance unitaire.}

L'augmentation de la puissance unitaire a été permise par les possibilités de la construction soudée, par les recherches des laboratoires d'essais qui ont permis des mesures précises et par des essais pratiqués sur de grosses machines industrielles. Ces essais ont amélioré la connaissance des problèmes de poussée, d'efforts de vannage et d'efforts sur les paliers (fig. 19).

La puissance unitaire des Kaplan atteint et dépasse même $100000 \mathrm{ch}$. Nous avons offert récemment, avec d'autres constructeurs, des machines de $150000 \mathrm{ch}$ et même, en variante, de $210000 \mathrm{ch}$, sous $20 \mathrm{~m}$ de chute.
Most of the points already discussed in connection with Pelton and Francis turbines also apply to Kaplan turbines.

\section{Increases in output.}

Higher individual turbine outputs have been made possible by modern welded construction methods, by the more accurate methods of measurement developed from experimental laboratory research, and by tests carried out on big industrial machines. The latter have provided fresh information about problems associated with turbine thrust, guide vane operating forces and bearing loads (Fig. 19).

Individual Kaplan turbine outputs have now reached and passed the 100,000 HP mark. We ourselves have recently tendered with other manufacturers for $150,000 \mathrm{HP}$ and even 210,000 


\section{Augmentation de la puissance spécifique.}

La puissance spécifique caractéristique, c'està-dire celle d'une roue de $1 \mathrm{~m}$ de diamètre, sous $1 \mathrm{~m}$ de chute $\left(\mathrm{N}_{11}\right)$, est passée de $20 \mathrm{ch}$ en 1920 à $24 \mathrm{ch}$ en 1945 et à $27 \mathrm{ch}$ à l'heure actuelle. Avec un aspirateur coudé, la limite se situe aux environs de $30 \mathrm{ch}$, puissance pour laquelle l'énergie totale se retrouve sous forme d'énergie cinétique à la sortie de la roue. Ce qui a permis une réduction sensible des dimensions et par conséquent du prix des turbines.

\section{Augmentation des chutes.}

Nous avons assisté à la concurrence entre les Kaplan et les Francis pour les chutes élevées,
HP units which are to operate under a head of $20 \mathrm{~m}$.

\section{Increases in specific output.}

The characteristic specific output of Kaplan turbines-i.e. the output obtainable from a runner $1 \mathrm{~m}$ in diameter under a $1 \mathrm{~m}$ head $\left(\mathrm{N}_{11}\right)$ -has steadily increased from $20 \mathrm{HP}$ in 1920 to $24 \mathrm{HP}$ in 1945 , and to $27 \mathrm{HP}$ today. With a draught elbow, the limit would appear to lie somewhere around the $30 \mathrm{HP}$ mark, which is the output at which the total energy occurs as kinetic energy at the runner exit. This development has resulted in an appreciable reduction in turbine dimensions, and hence also in their cost.
Fig. 19

Seyssel (France). 3 turbines liaplan. Puissance : $14850 \mathrm{~kW}$

Chute : $9,5 \mathrm{~m}$

Vitesse : $75 \mathrm{tr} / \mathrm{mn}$.

Diamètre de roue : $6300 \mathrm{~mm}$.

Mise en place d'un groupe.

Selyssel, France.

Three Kaplan turbines.

Output: $14,850 \mathrm{~kW}$.

Head: $9.5 \mathrm{~m}$

Speed: 75 r.p.m.

Runner diameter: $6,300 \mathrm{~mm}$.

Installing a turbine

in the power house.

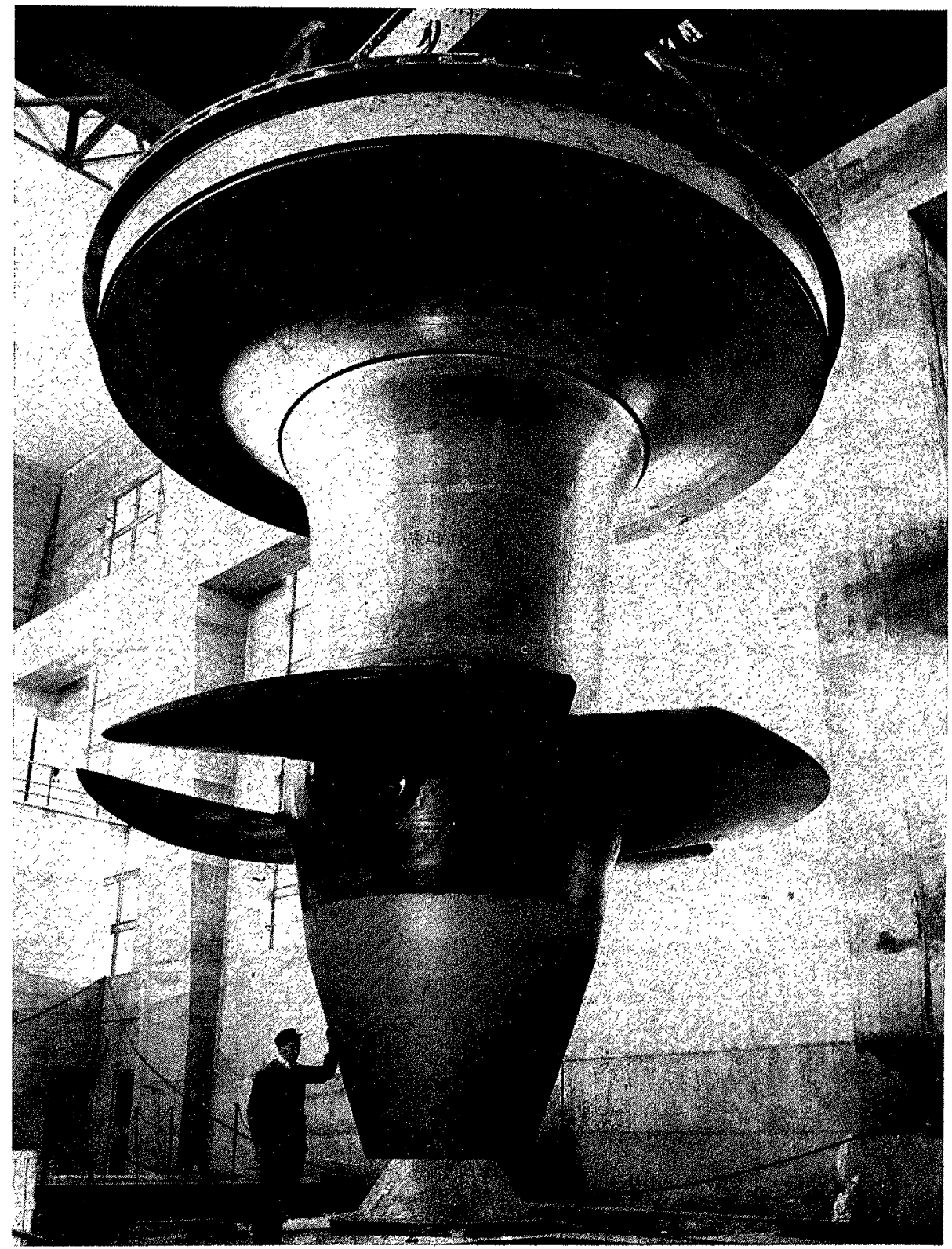

(Cliché Neyrpic.) 
de $40 \mathrm{~m}$ à $70 \mathrm{~m}$, comme les Francis étaient entrées en concurrence avec les Pelton.

Cependant cette évolution paraît arrêtée à l'heure actuelle. Si des Kaplan de forte puissance $(35$ à $40000 \mathrm{ch})$ ont atteint et dépassé

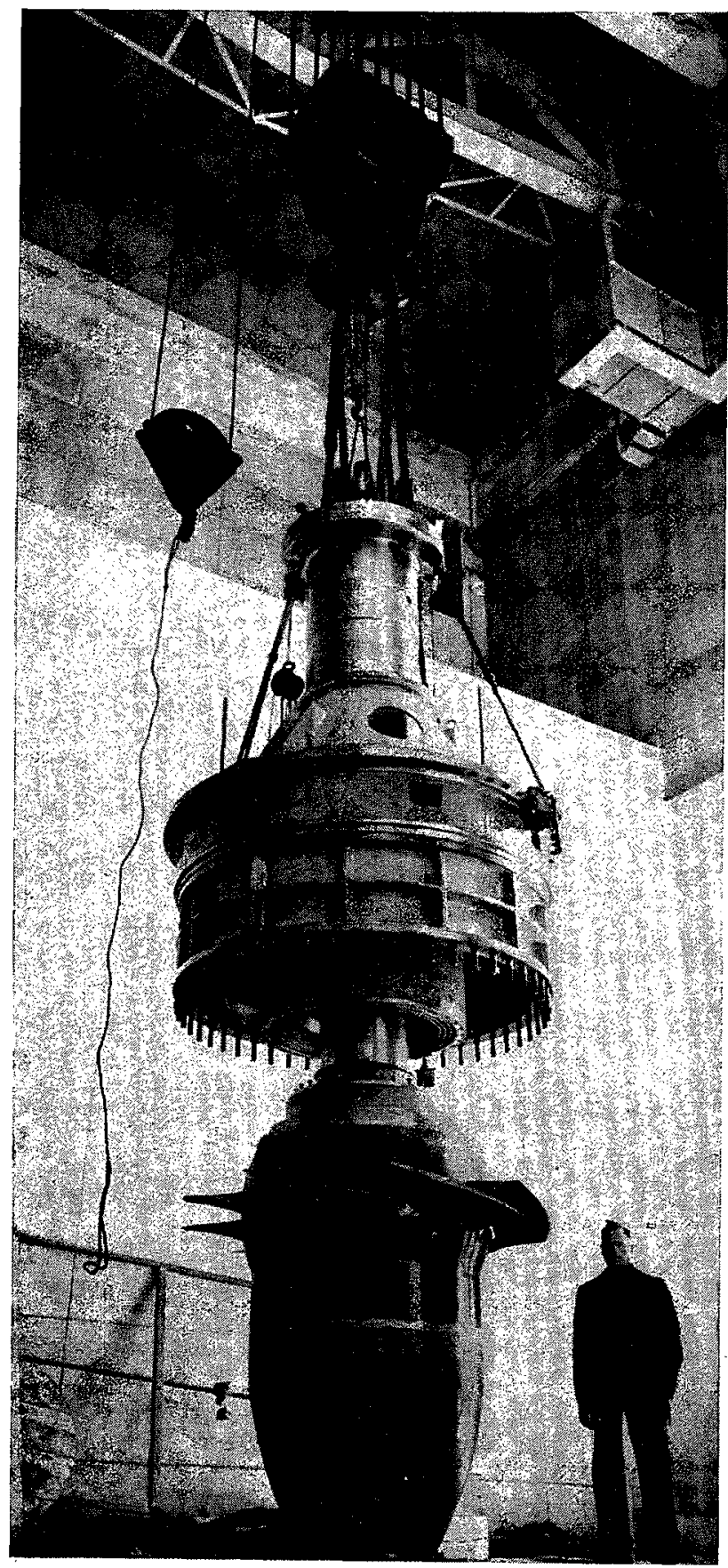

Fig. 20

(Cliché Neyropic.)

Bort, groupe de la Rhue (France). 1 turbine Kaplan. Puissance : $23000 \mathrm{~kW}$. Chute: $85 \mathrm{~m}$.

Vitesse : $375 \mathrm{tr} / \mathrm{mn}$. Diamètre de roue : $2300 \mathrm{~mm}$.

Bort (on the Rhue), France. One Kaplan turbine. Output: 23,000 $\mathrm{kW}$. Head: $85 \mathrm{~m}$.

Speed: 375 r.p.m. Runner diameter: $2,300 \mathrm{~mm}$. Installing the turbine in the power house.

\section{Increases in head.}

Kaplan and Francis turbines have been competing in the $40 \mathrm{~m}$ to $70 \mathrm{~m}$ head range much in the same way as Francis and Pelton turbines at the other end of the head scale. This trend now seems to have reached a stationary stage, however, for though some high-power Kaplan turbines producing $35,000 \mathrm{HP}$ to $40,000 \mathrm{HP}$ under a $70 \mathrm{~m}$ head were built between 1955 and 1957, more recent units do not appear to have gone beyond $40 \mathrm{~m}$ to $50 \mathrm{~m}$ (Fig. 20).

The hub diameter of a Kaplan turbine increases with the head, which gives rise to increasing difficulties with cavitation. Under such conditions, the Kaplan turbine is a less attractive proposition than the comparable high specific speed Francis machine. The resulting fall-off in its efficiency is already quite appreciable at heads above about $35 \mathrm{~m}$, and in order to improve its coefficient of cavitation, the machine would either have to be set lower than the corresponding Francis turbine or be given a bigger runner diameter, which would make it less economical.

The high-head Kaplan turbine nevertheless has certain advantages over the Francis turbine where both head and output are liable to vary a lot at the same time. It is also less vulnerable to wear.

\section{Increases in turbine efficiency.}

As with the Francis turbine, Kaplan efficiencies have definitely increased, though they have now reached such a high level that it is

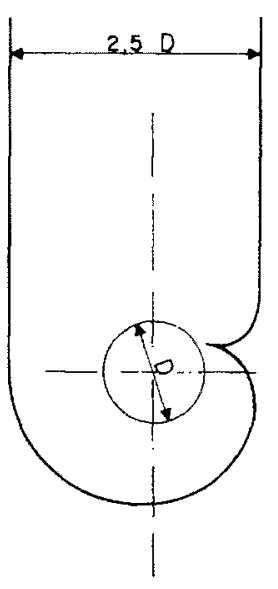

FIG. 21

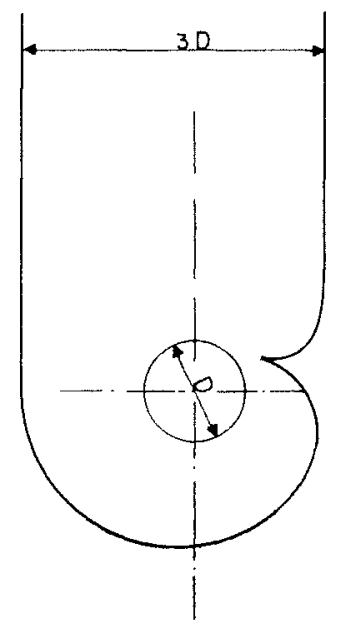
Kaplan turbine spiral casing outlines. 
$70 \mathrm{~m}$ de chute vers 1955-1957, depuis lors les réalisations semblent plafonner autour de chutes de 40 à $50 \mathrm{~m}$ (fig. 20).

A mesure qu'augmente la chute, le moyeu devient de plus en plus gros, entraînant des difficultés au point de vue de la cavitation. La Kaplan est alors moins favorable que la Francis, de vitesse spécifique élevée, qui pourrait lui être comparée. La baisse de rendement résultante devient assez sensible, même à partir de chutes de l'ordre de $35 \mathrm{~m}$. Pour améliorer le coefficient de cavitation, il faudrait enfoncer davantage la Kaplan que la Francis correspondante, ou bien il faudrait augmenter le diamètre de roue, ce qui conduirait à une machine moins économique.

La Kaplan de haute chute garde cependant des avantages par rapport à la Francis si la chute et la puissance sont simultanément très variables. Elle présente aussi l'avantage d'une moindre usure.

\section{Augmentation des rendements.}

Les rendements ont certes progressé mais, comme en Francis, ils atteignent de telles altitudes qu'il paraît difficile d'aller beaucoup plus loin. De plus, les essais de machines industrielles se heurtent à de grandes difficultés pratiques, si bien que les mesures sur le site sont à peu près abandonnées et les marchés comportent souvent une clause d'essai sur modèle réduit. Il convient alors de se mettre d'accord sur une formule de transposition pour déterminer le rendement de la machine industrielle, formule toujours plus ou moins discutable, comme les conditions de mesure, ce qui rend les comparaisons difficiles d'une installation à l'autre.

Pour améliorer les rendements, les roues ne sont pas seules en cause; l'amélioration des amenées, pour les faibles puissances spécifiques, et celle des aspirateurs, pour les grandes puissances spécifiques, présente au moins autant d'importance.

\section{Dispositions constructives.}

LES BACHES.

Le tracé des bâches a une grande répercussion sur le rendement. Par ailleurs, la technique a permis d'en réduire sensiblement l'encombrement pour diminuer les frais de génie civil. Cette réduction s'est opérée aussi bien sur la largeur que sur la hauteur des pertuis d'entrée, ce qui entraîne des vannes de garde plus petites, et un entre-axes des groupes moindre, donc une centrale moins longue (fig. 21).

On a poussé l'utilisation des bâches en béton vers les hautes chutes dans un but d'économie. LES DISTRIBUTEURS.

Les progrès effectués pour les Francis ont été difficult to see how they could go much further. In addition, major practical difficulties have been encountered in the testing of industrial machines, to such a point in fact that practically no more tests are being carried out on site, and contracts frequently specify tests on a scale model instead. In this case, the formula to be applied for the conversion of model efficiencies into prototype efficiencies has to be agreed upon beforehand, just like the test conditions; as these formulae are always more or less open to discussion, it is generally difficult to compare the performance of one plant with that of another.

Efficiencies can also be improved in other ways than by modifying the runner; at least as much can be achieved by improvements to the intake designs and draught tubes of low and high specific head machines respectively.

\section{Component design trends.}

\section{Spiral Casings.}

Spiral casing design has a considerable bearing on Kaplan turbine efficiency. Technical improvements have made it possible to considerably reduce the dimensions of this component, which has resulted in correspondingly lower civil engineering costs. Both the height and breadth of the casing intake openings have been reduced, so that it has been possible to use smaller shut-off valves and to install the turbine closer together, with narrower power station buildings as the result (Fig. 21).

The practice of building concrete volutes has been developed for high-head applications, again with a view to greater economy.

\section{Guide VANE ASSEMblies.}

The improvements developed under this heading for Francis machines have also been extended to Kaplan turbines, including such things as improved stay vane assembly and head cover designs and the possibility of giving each guide vane its own servomotor, the latter especially in view of the very large dimensions of Kaplan turbine. Several methods have also been developed to enable the guide vanes to be dismantled without first having to remove the head covers.

\section{RUNNERS.}

A number of different ways of dismantling individual runner blades from the runner in 


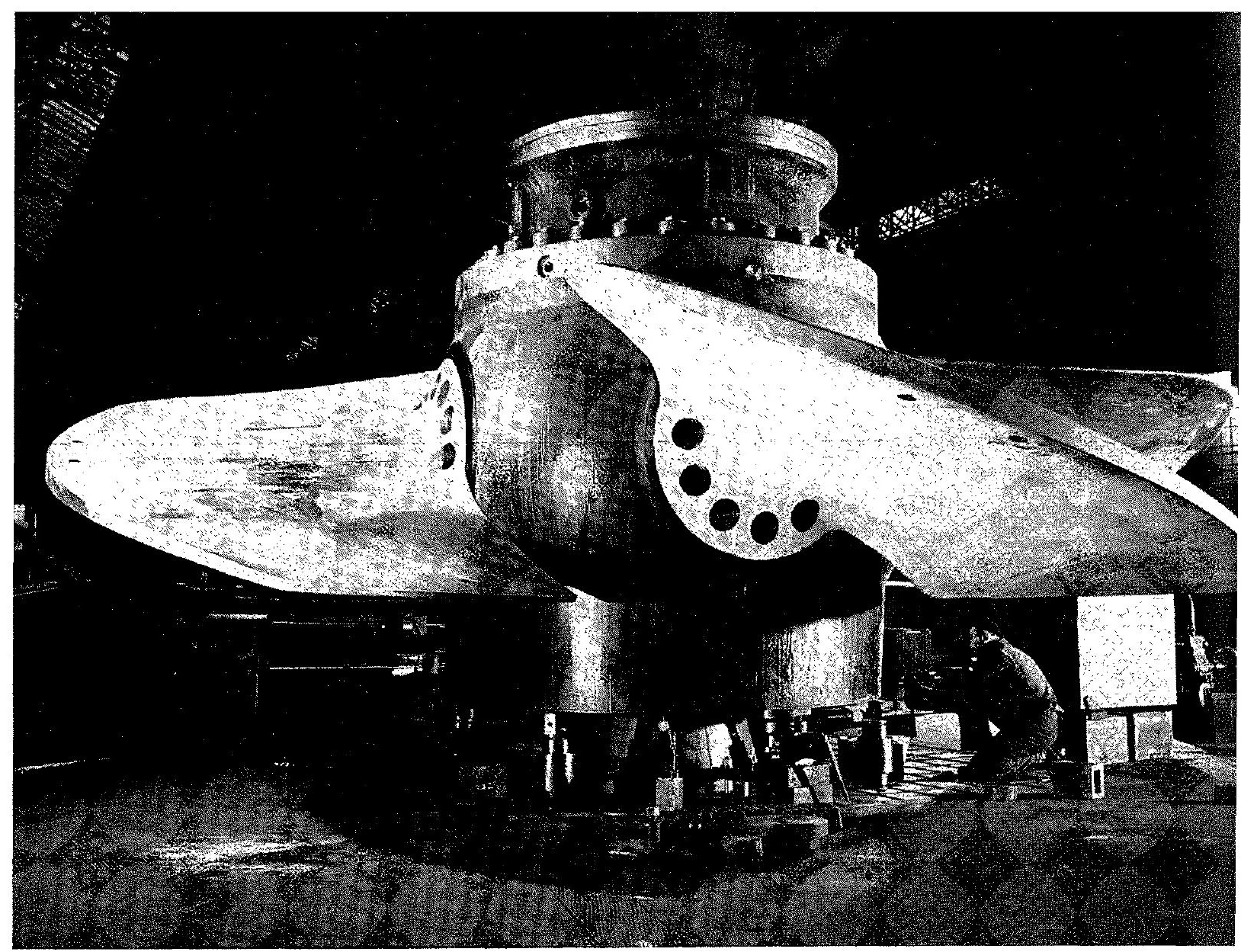

(Cliché Neyrpic.)

appliqués aux Kaplan : amélioration du calcul des avant-distributeurs et des fonds, possibilité de servo-moteurs de vannage individuels en tête de chaque directrice, eu égard aux très grandes dimensions des Kaplan. Le démontage des direc- situ have been devised (Fig. 22). In one of these, access to the blades is gained through the throat ring, which is specially provided with a removable section for the purpose; in another, the blades are passed out through the guide

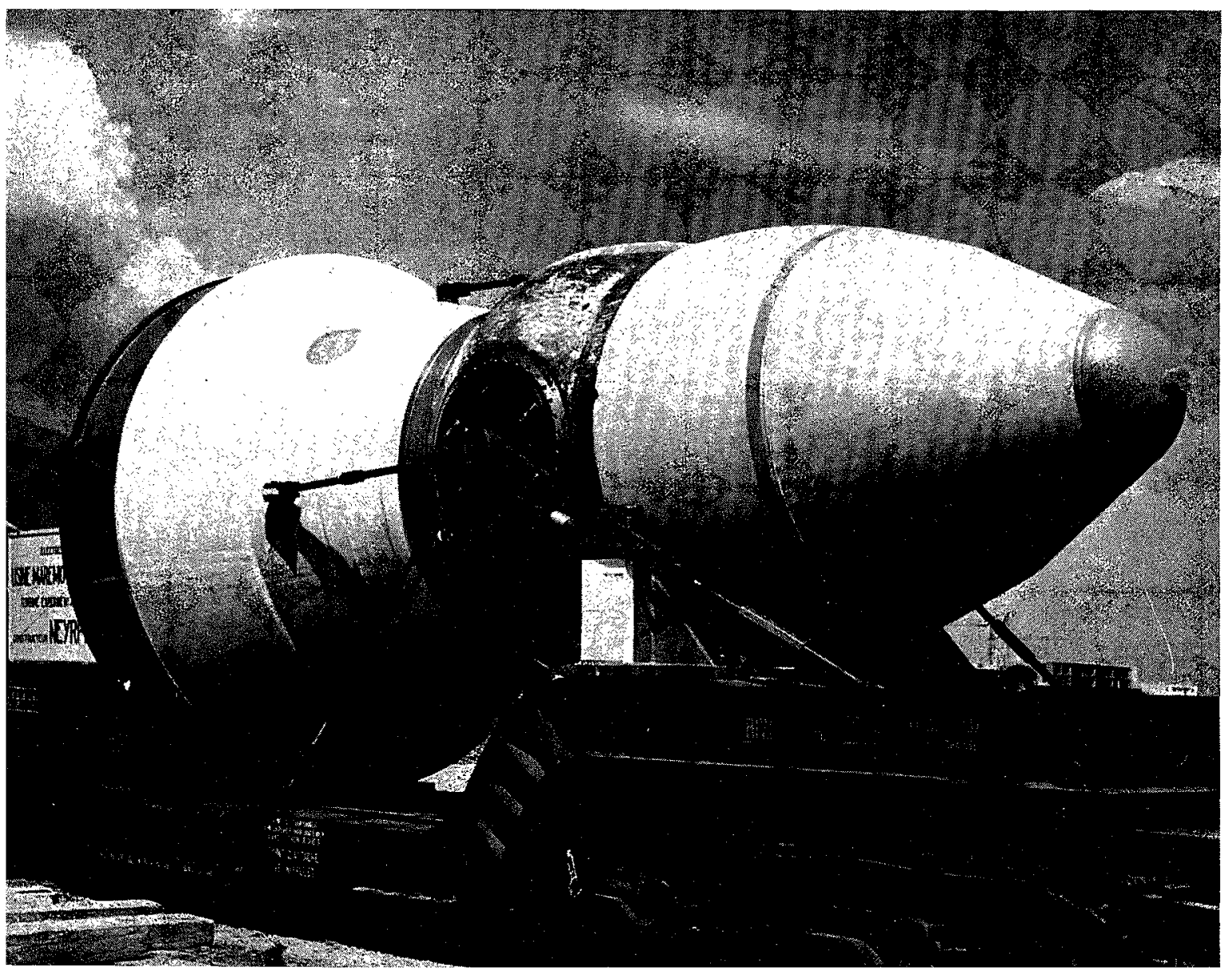

FIG. 23

Saint-Malo (France).

Usine marémotrice.

1 groupe bulbe amont.

Puissance : $9000 \mathrm{~kW}$.

Chute : $6 \mathrm{~m}$.

Vitesse : $88 \mathrm{tr} / \mathrm{mn}$

Diamètre de roue : $5800 \mathrm{~mm}$

Moulinet complet,

sans Ies pales,

chargé sur wagon spécial

pour l'expédition

a la centrale.

Saint-Malo tidal plant,

France.

One upstream-bulb unit.

Output: $9,000 \mathrm{~kW}$.

Head: 6 m. Speed: 88 r.p.m. Runner diameter: $5,800 \mathrm{~mm}$.

The runner hub assembly

ready to leave

for the power site

on a special railway truck. 
FIG. 24

Rochedo (Brésil). 1 turbine Kaplan. Puissance : $4000 \mathrm{~kW}$. Chute : $17,6 \mathrm{~m}$

Vitesse : $257 \mathrm{tr} / \mathrm{mn}$ Diamètre de roue : $2070 \mathrm{~mm}$. Ensemble de la turbine.

Rochedo, Brazil. One Kaplan turbine. Output: $4,000 \mathrm{~kW}$. Head: $17.6 \mathrm{~m}$. Speed: 257 r.p.m.

Runner diameter: $2,070 \mathrm{~mm}$. General turbine assembly.

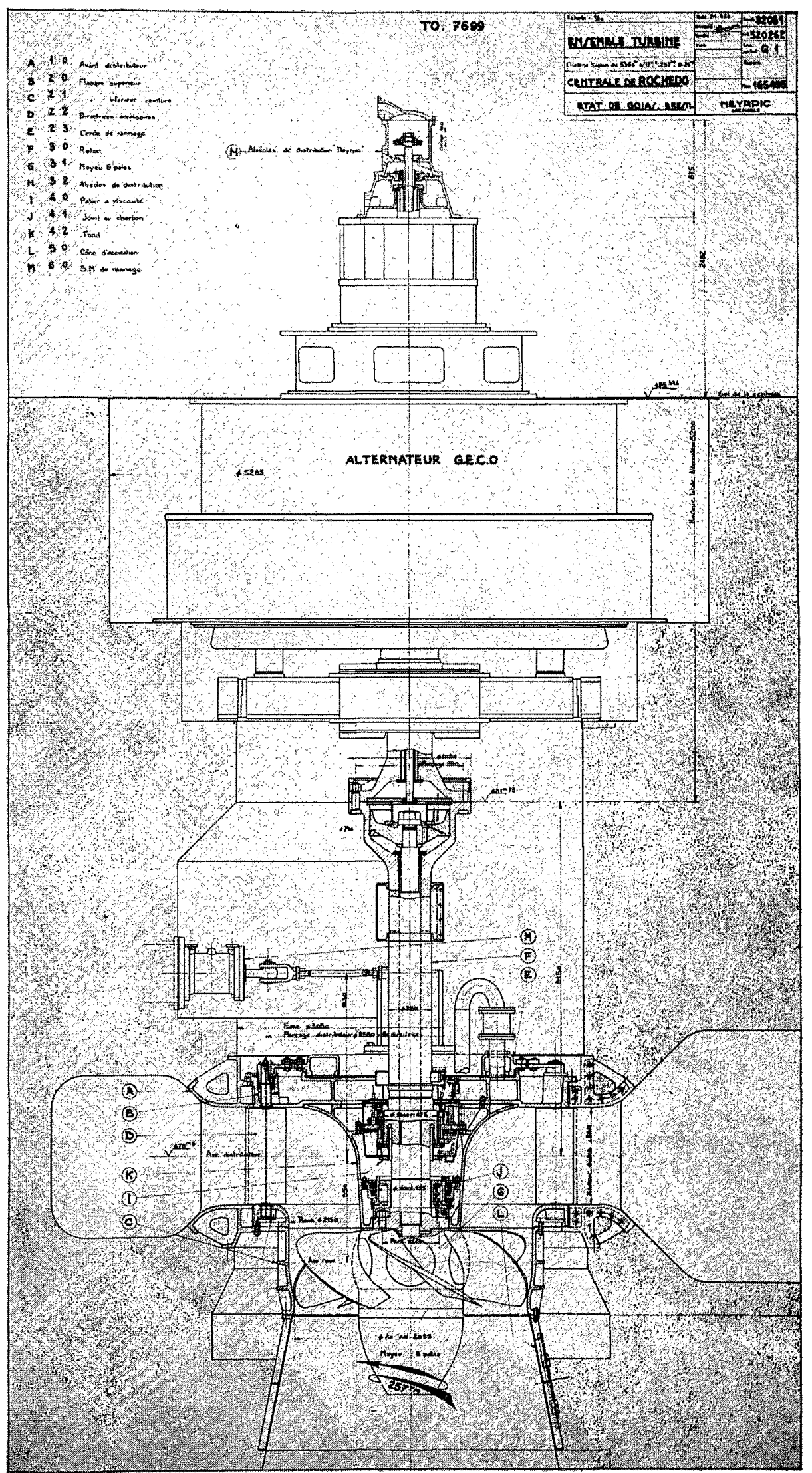




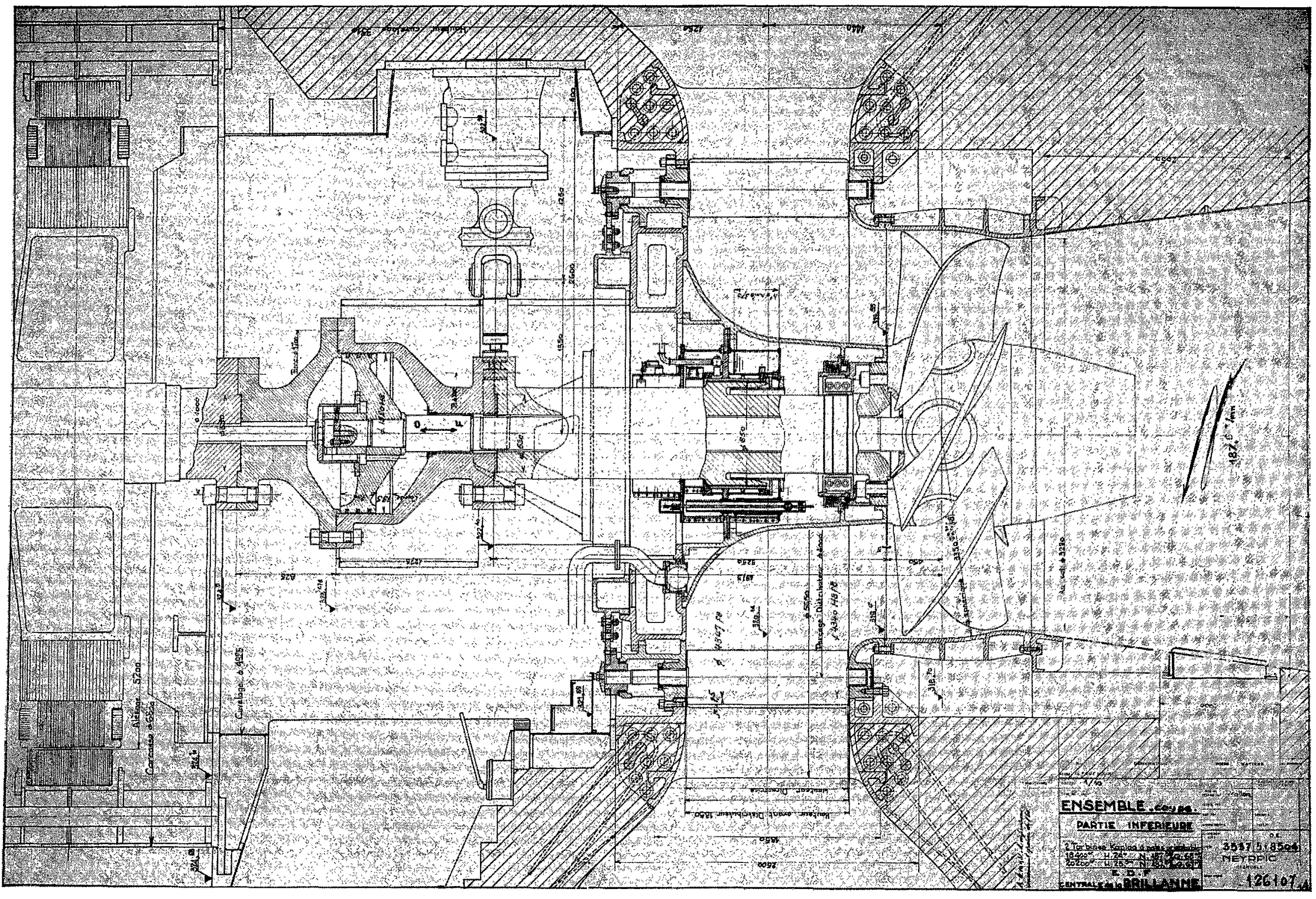

FiG. 25

La Brillanne (France), 2 turbines Kaplan.

: $24 \mathrm{~m}$. Vitesse : $187,5 \mathrm{tr} / \mathrm{mn}$. Diamètre de roue : $3350 \mathrm{~mm}$. Coupe verticale d'une turbine.

La Brillanne, France. Two Kaplan turbines.

Output: 14,700 kW. Head: $24 \mathrm{~m}$. Speed: 187.5 r.p.m. Runner diameter: $3,350 \mathrm{~mm}$. 


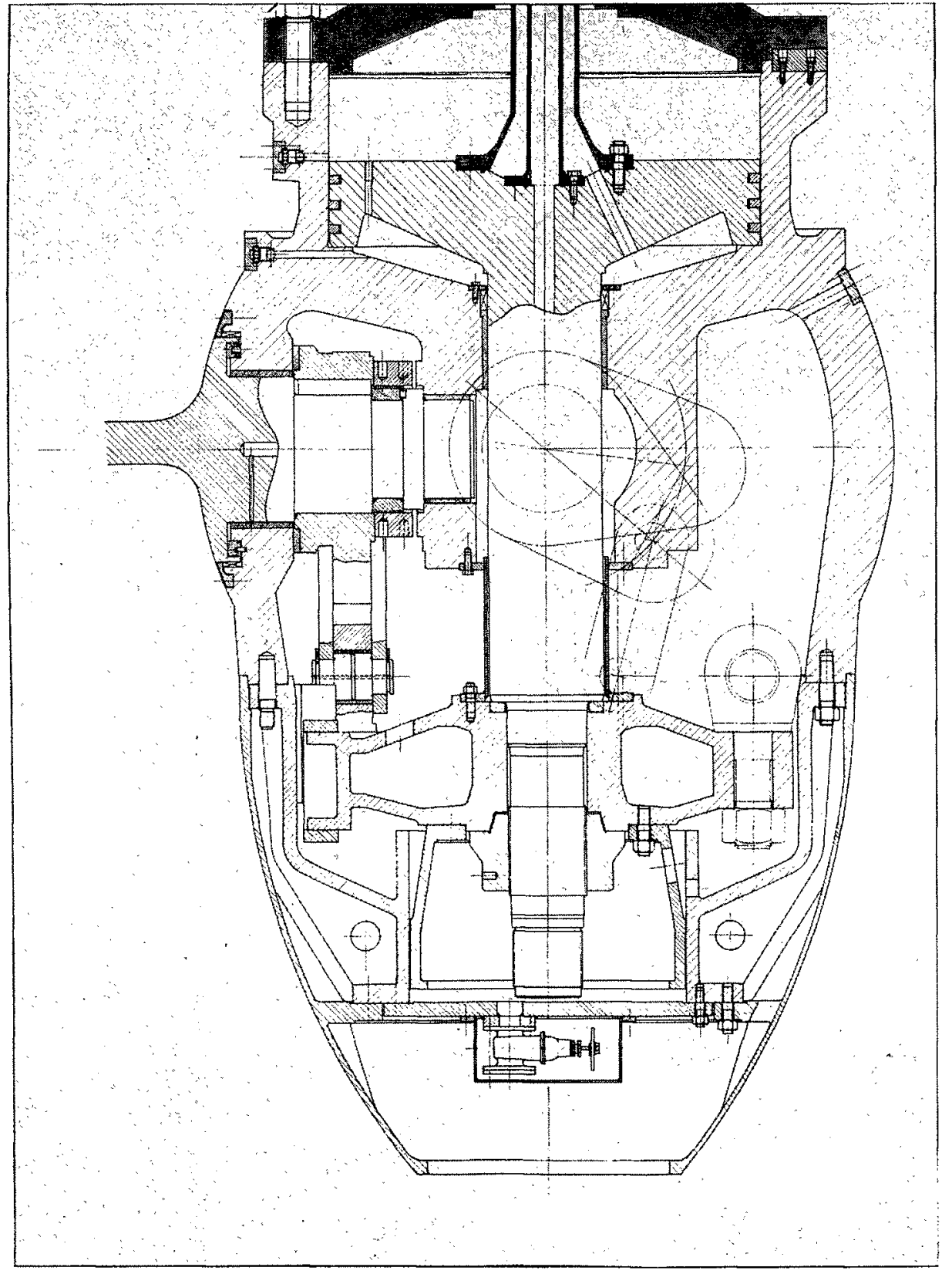

Fig. 26

Salto Grande (Brésil). 4 turbines Kaplan.

Puissance: $18300 \mathrm{~kW}$. Chute : $16 \mathrm{~m}$. Vitesse : $128 \mathrm{tr} / \mathrm{mn}$ Diamètre de roue : $4400 \mathrm{~mm}$. Coupe d'une turbine.

Salto Grande, Brazil. Four Kaplan turbines.

Output: 18,300 kW. Head: $16 \mathrm{~m}$. Speed: 128 r.p.m. Runner diameter: 4,400 mm. Vertical runner hub cross-section.

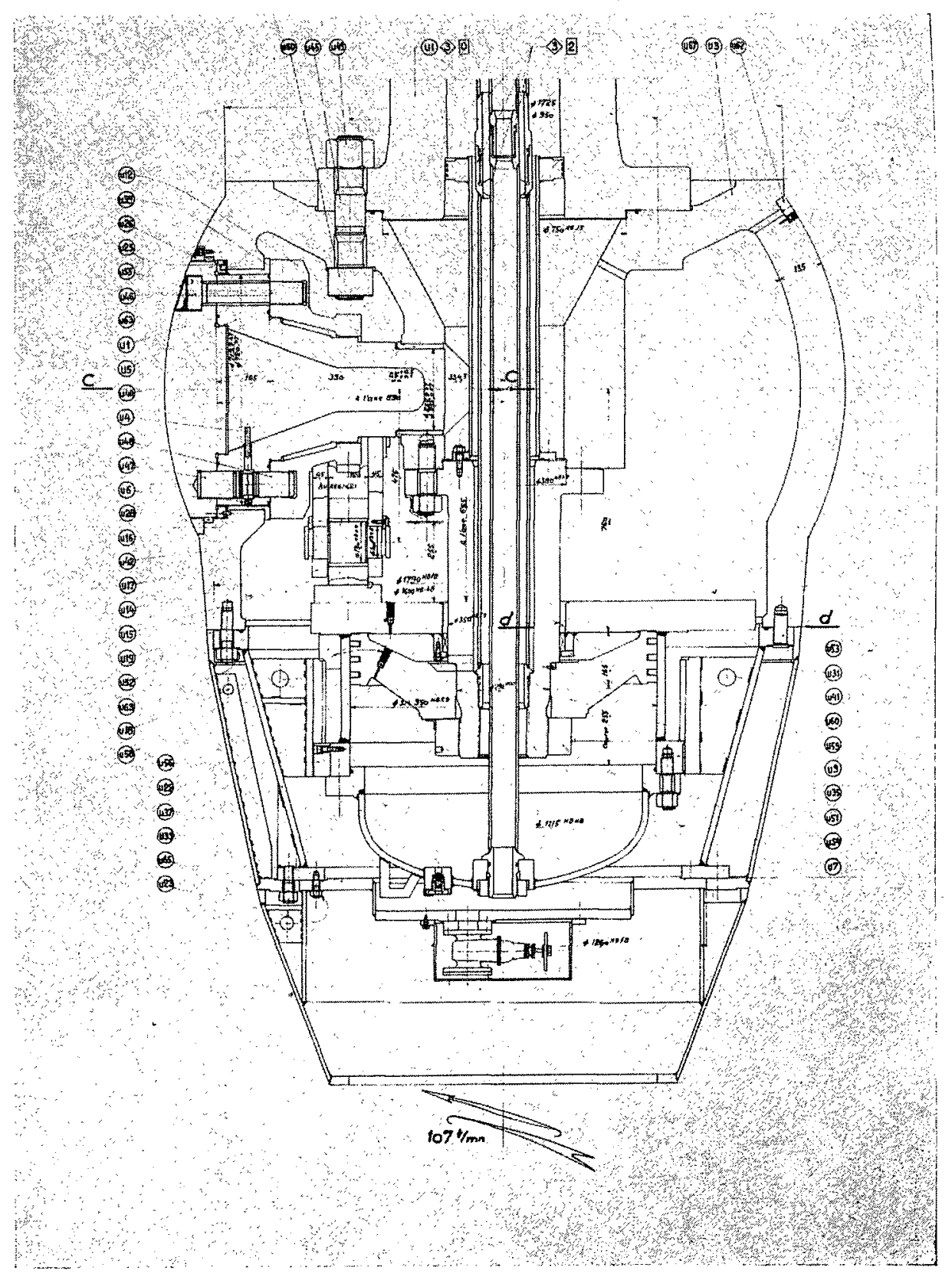

Fig. 27

Saint-Hilaire-du-Rosier (France). 3 turbines Kaplan. Puissance : $13200 \mathrm{~kW}$. Chute : $11,5 \mathrm{~m}$. Vitesse : $107,2 \mathrm{tr} / \mathrm{mn}$. Diamètre de roue : $5000 \mathrm{~mm}$. Coupe d'une roue.

Saint Hilaire du Rosier, France. Three Kaplan turbines.

Output: $13,200 \mathrm{~kW}$. Head: $11.5 \mathrm{~m}$. Speed: 107.2 r.p.m. Runner diameter: $5,000 \mathrm{~mm}$. Vertical runner hub cross-section. 
trices, sans démontage préalable des flasques, a fait l'objet de nombreuses réalisations.

\section{LES ROUES.}

Le démontage individuel des pales de la roue sans démonter cette dernière, pour faciliter l'entretien, a reçu différentes solutions (fig. 22). Les pales sont démontées soit au travers de la ceinture, qui comporte une partie amovible, soit en les passant au travers du distributeur. D'une manière générale, pour les grandes dimensions, les pales rapportées sur le moyeu s'imposent. La pale, devenue indépendante de son tourillon de manœuvre, peut être enlevée pour le transport de l'usine à la centrale; le moyeu part seul et les pales sont rapportées au montage (fig. 23). Pour des roues de 7 à $8 \mathrm{~m}$ de diamètre, cela facilite évidemment beaucoup le transport. vane assembly. Composite blades are generally to be recommended for the larger turbines, so that, as they are independent of the blade operating stems, they may be removed for transport to the power station, leaving the hub to travel by itself. The blades are then refitted when the turbine is assembled (Fig. 23). In the case of a runner $7 \mathrm{~m}$ or $8 \mathrm{~m}$ in diameter, this feature goes a long way towards ironing out transport difficulties.

\section{RUNNER BLADE SERVOMO'TOR.}

The position of this component inside the turbine has changed several times during recent years. In older designs, it was an integral part of the turbine shaft, which therefore had

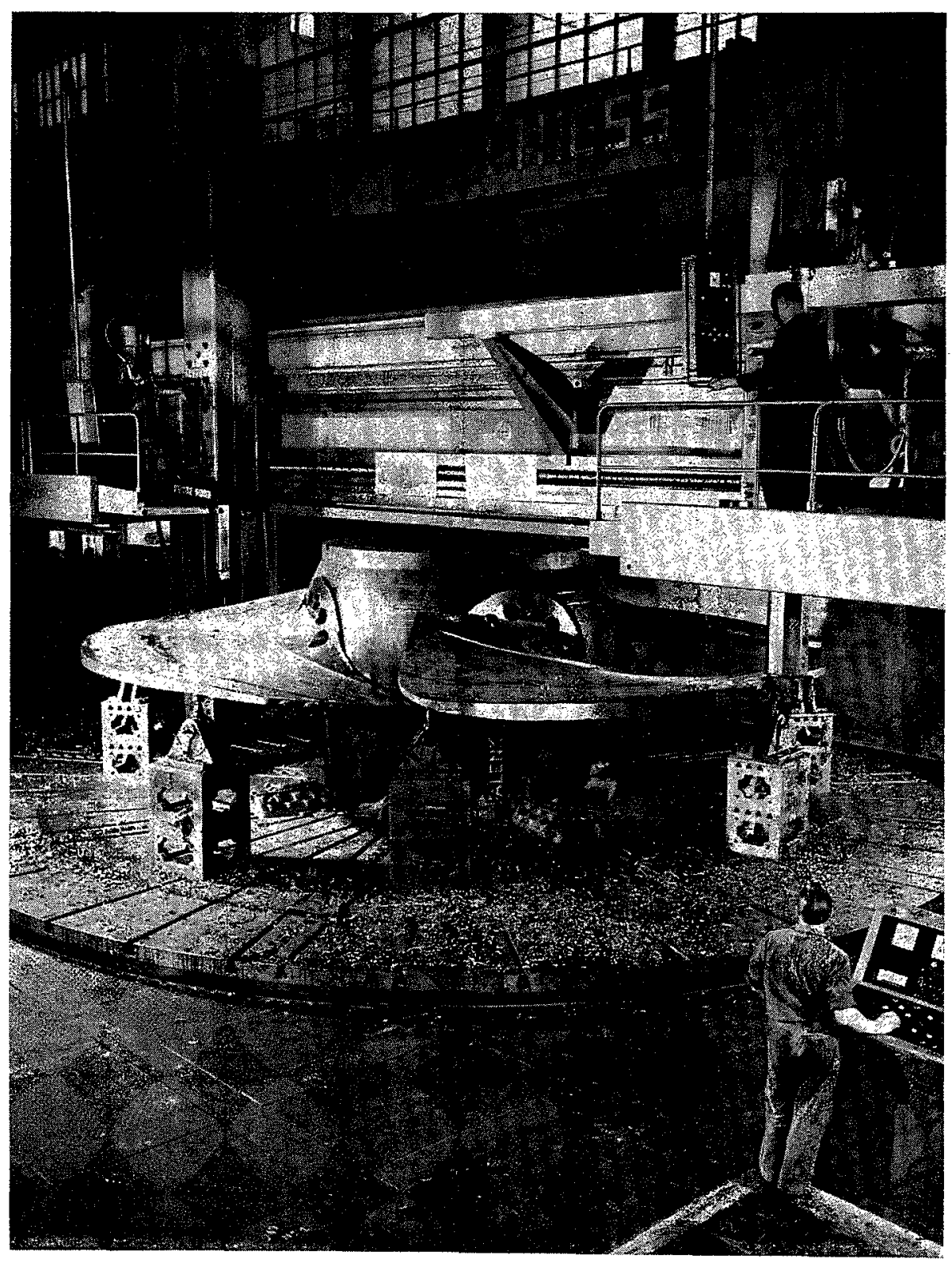

(Cliché Neyrpic.)
Fia. 28

Marckolsheim

(caractéristiques : voir fig. 22 ).

Tournage du diamètre extérieur d'une roue.

Marckolsheim,

(characteristics: see Fig. 22).

Machining

of runner blade edges. 
LE SERVO-MOTEUR DE MANCEUVRE DES PALES.

L'emplacement du servo-moteur des pales a changé plusieurs fois au cours des dernières années. Dans les conceptions anciennes, il faisait corps avec l'arbre, ce qui conduisait à une pièce de forge compliquée, chère, difficile à usiner (fig. 24). On a commencé par rapporter le servo-moteur au sommet d'un arbre ordinaire; afin de faciliter la forge et l'usinage de cet arbre (fig. 25); puis on a placé le servomoteur directement au-dessus de la roue (fig. 26); enfin, quand cela est possible, on l'inclut dans le moyeu de la roue pour les grandes dimensions et les très basses chutes (fig. 27).

\section{LA ROUE.}

Le choix du métal des pales présente de l'intérêt, car les fatigues assez élevées, notamment à l'attache, et surtout la crainte de la cavitation conduisent à l'acier à $13 \%$ de chrome, en raison de ses caractéristiques mécaniques et de sa résistance à la corrosion (fig. 28). Toutefois, pour les basses chutes, et si le calage est satisfaisant, on peut garder un acier au carbone à haute résistance.

Cependant, dans les Kaplan à axe horizontal, c'est-à-dire les turbines-bulbes dont nous parlerons par la suite, on a quelquefois adopté le bronze d'aluminium qui résiste très bien à la cavitation et se révèle très facile à souder, à l'inverse de l'acier à $13 \%$ de chrome. Une partie des turbines marémotrices de la Rance sera équipée de pales en bronze. to be an expensive complicated forging which was also very difficult to machine (Fig. 24). The practice then developed of fitting the servomotor to the top end of an ordinary turbine shaft (Fig, 25) as a solution to the forging and machining problem. Next, a place was found for the servomoteur directly above the runner (Fig. 26), and the present practice on big machines and very low head applications is to accommodate it inside the runner hub (Fig. 27).

\section{TuRbine RUNNer.}

The choice of a suitable metal for the runner blades is important; it has been found that $13 \%$ chrome stainless steel has the mechanical characteristics and corrosion resistance required to stand up to the fairly considerable metal fatigue affecting the blades (particularly at their mountings) and to successfully withstand cavitation (Fig. 28). For lower heads, however, and providing the turbine is set at a suitable level, high-tensile carbon steel can quite safely be used for these components.

Aluminium bronze blades have occasionally been used in horizontal-shaft Kaplan Lurbines, or more specifically the bulb turbines which we shall be discussing later on. This material not only stands up very well to cavitation, but, contrary to $13 \%$ chrome stainless steel, it also welds very easily. Some of the turbines in the Rance tidal power plant are to be provided with bronze runner blades.

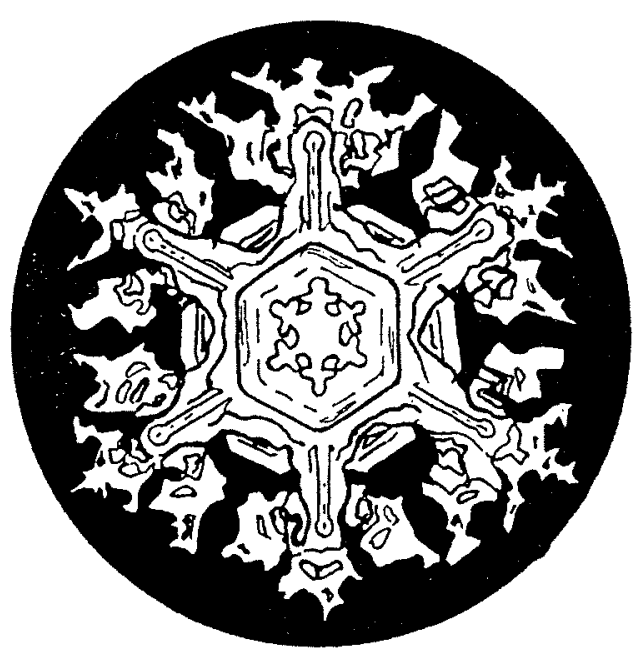

